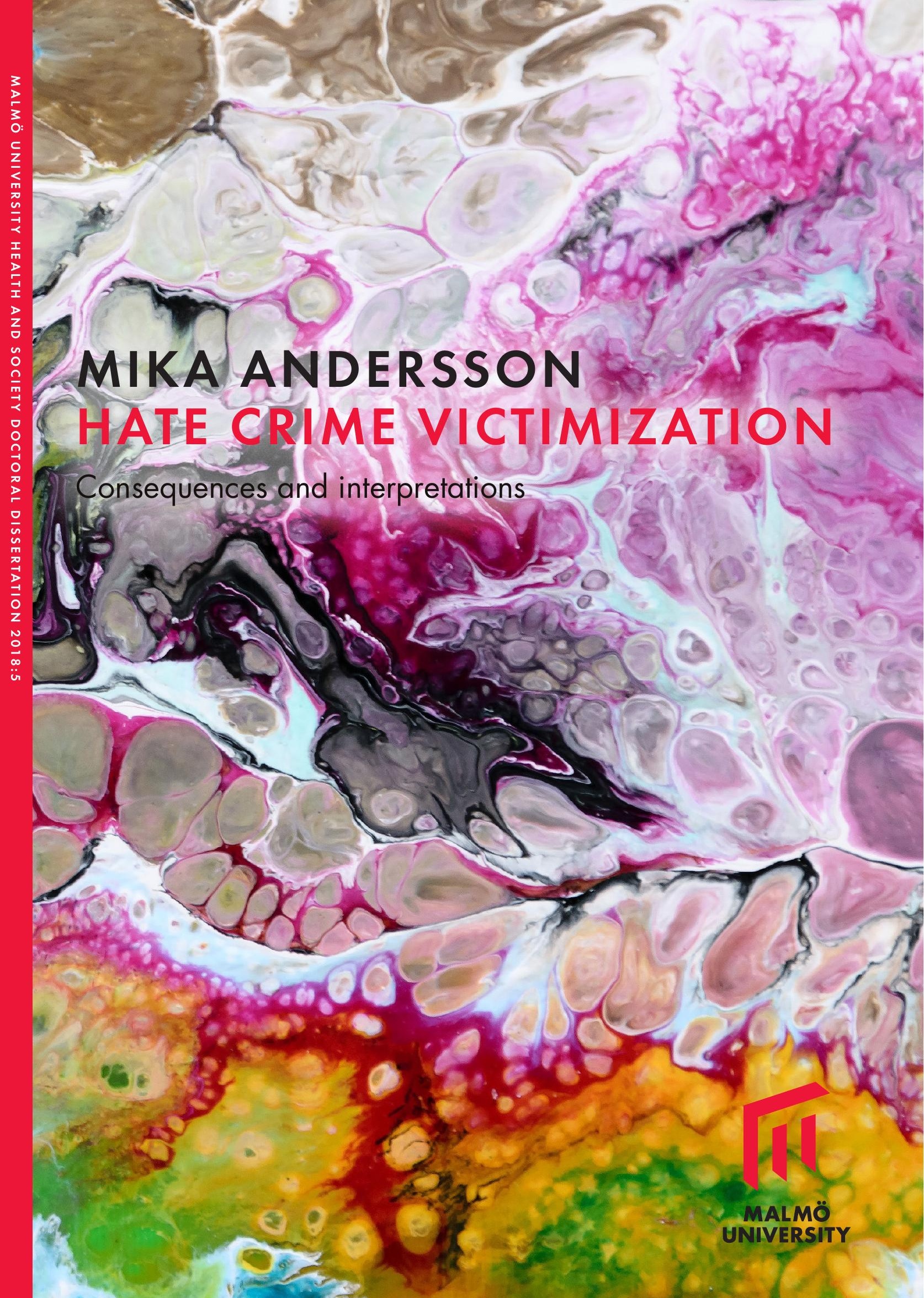



HATE CRIME VICTIMIZATION: CONSEQUENCES AND INTERPRETATIONS 
Malmö University Health and Society, Doctoral Dissertation 2018:5

(C) Mika Andersson 2018

Illustration: Michael Lønfeldt

ISBN 978-9I-7IO4-9I6-2 (print)

ISBN 978-9I-7IO4-9I7-9 (pdf)

ISSN $1653-5383$

Holmbergs, Malmö 2018 


\section{MIKA ANDERSSON HATE CRIME VICTIMIZATION}

Consequences and interpretations

Malmö University, 2018 Faculty of Health and Society 
This publication is also available at:

http://dspace.mah.se/handle/2043/24837 
"In the Genealogy of Morals, Friedrich Nietzsche, as so many before and after, describes the "unbroken progress in the self-belittling of man" brought about by the scientific revolution. Nietzsche mourns the loss of "man's belief in his dignity, his uniqueness, his irreplaceability in the scheme of existence." For me, it is far better to grasp the Universe as it really is than to persist in delusion, however satisfying and reassuring. Which attitude is better geared for our long-term survival? Which gives us more leverage on our future? And if our naïve self-confidence is a little undermined in the process, is that altogether such a loss? Is there not cause to welcome it as a maturing and characterbuilding experience?” 



\section{CONTENTS}

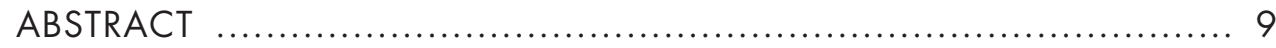

LIST OF PAPERS ........................................................ 11

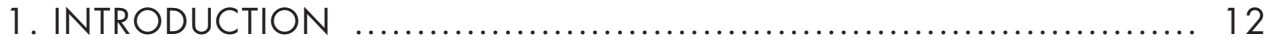

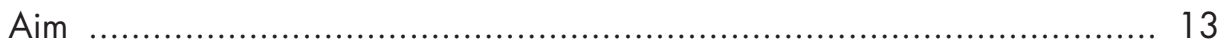

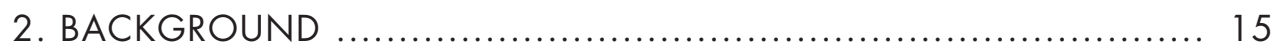

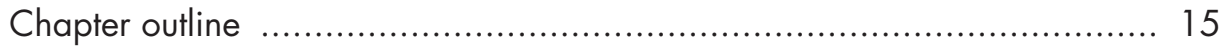

Hate crime narratives in the Swedish policy domain ........................... 15

Official hate crime statistics in Sweden .............................................. 19

Research on hate crime victimization in Sweden .................................. 22

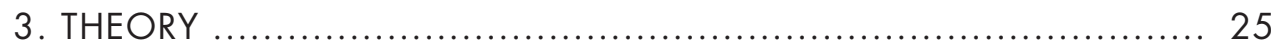

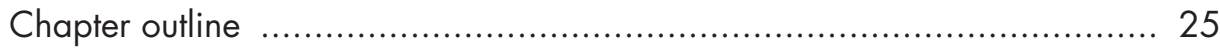

Theoretical frameworks for understanding group conflicts ....................... 25

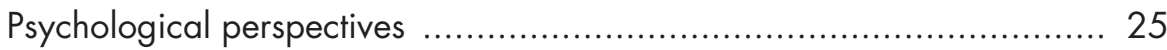

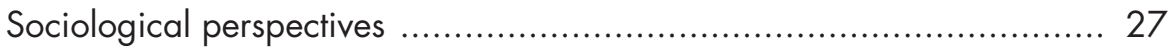

Intersectional perspectives ....................................................... 28

Criminological frameworks for understanding causes of hate crime ........... 29

An integrated approach to hate crime causation ................................. 34

Theoretical frameworks for understanding consequences of hate crime ....... 36

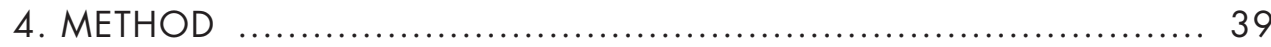

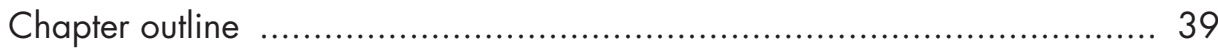

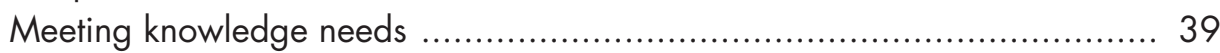

Group categories included in the study .......................................... 41

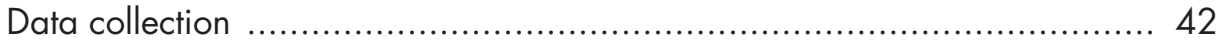

Ethical considerations ..................................................................... 45 


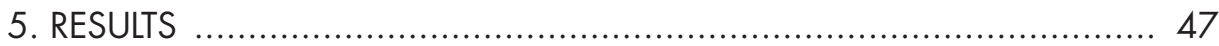

Chapter outline .............................................................................. 47

Article 1: Consequences of bias-motivated victimisation among Swedish university students with an immigrant or minority background ................. 47

Article 2: When there is more than one motive: a study on self-reported hate crime victimization among Swedish university students ..................... 49

Article 3: How victims conceptualize their experiences of hate crime ........... 51

Article 4: Does having friends with experiences of hate crime increase fear of crime among women, sexual minorities and Muslims? ................... 53

6. DISCUSSION ........................................................ 56

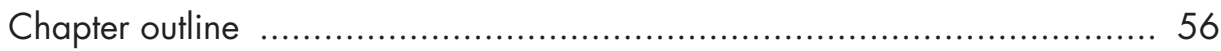

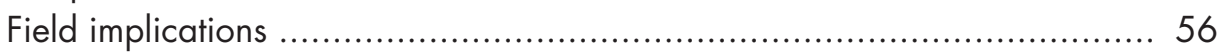

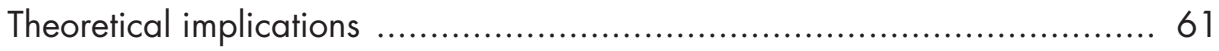

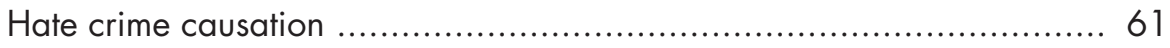

Consequences of hate crime .................................................... 63

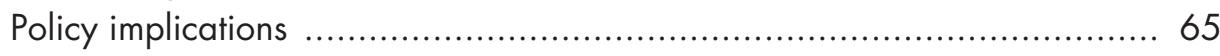

POPULÄRVETENSKAPLIG SAMMANFATTNING $\ldots \ldots \ldots \ldots \ldots \ldots \ldots \ldots . \ldots 7$

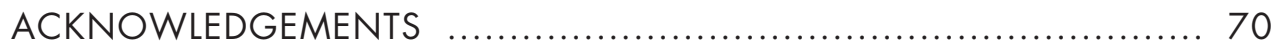

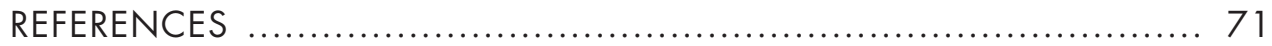

PAPERS IIV ........................................................ 77 


\section{ABSTRACT}

The present dissertation has two primary aims: 1) to test field assumptions and 2) develop present theoretical frameworks on causes and consequences of hate crime.

In Article 1, I and my co-author examine the assumption that hate crime victimization results in higher levels of fear in comparison to nonbias crime. In support of the assumption, the results showed that hate crime victims reported significantly higher levels of fear of crime in comparison to non-victims and non-bias victims.

In Article 2, I and my co-authors examine the assumption that police reporting is lower among victims of hate crime that targets more than one of their identity categories. Contrary to the assumption, we find that victims of hate crime with multiple motives report their experiences to the police to a higher extent in comparison to victims of single-motive hate crime.

In Article 3, I and my co-authors examine the assumption that hate targets the identity of the victim and thereby attacks the core of the victim's self. We found that hate crime targets a negative stereotype associated with the perceived identity of the victim. Consequently, interview participants did not regard hate crime as a direct attack on their selves since they did not identify with the negative stereotype. However, hate crime remains a violation of the self as it denies the victim self-representation.

In Article 4, I and my co-authors examine the assumption that vicarious victims respond similarly to direct victims since hate crime signals the presence of threat beyond the initial victim. This mechanism has been referred to as the in terrorem effect. We examine the in terrorem 
effect by comparing fear of crime between non-victims, vicarious victims of hate crime, and direct victims of hate crime. The results showed that fear of crime among non-victims, vicarious victims and direct victims did not follow the proposed pattern of the in terrorem effect.

Consequently, the results of Articles 1-4 call for a more complex understanding of both individual and community effects of hate crime.

In relation to hate crime offenses, I propose that individuals who commit hate crime directed downwards in a social hierarchy should have a poorly developed sense of self, a strong sense of entitlement to the servitude from those targeted, and endorse hierarchy-enhancing myths. Conversely, retaliatory hate crime should be committed by individuals who endorse hierarchy-attenuating myths. Hate crime occurring between or within stigmatized groups should be committed by individuals who endorse hierarchy-enhancing myths.

In relation to consequences of hate crime, I propose that detrimental consequences are enhanced when the victim belongs to a stigmatized group, has a strong group identity, and is correctly categorized by the offender. Victims who are targeted by members of their primary group should report more severe consequences in comparison to victims who are targeted by strangers. Moreover, victims who are targeted by members of their primary group should experience feelings of individual isolation, while victims targeted by strangers should experience feelings of isolation from society. Victims who belong to stigmatized groups and endorse hierarchy-enhancing myths should report higher levels of selfcontempt in comparison to those who reject hierarchy-enhancing myths. Lastly, victims who belong to stigmatized groups and reject hierarchyenhancing myths should report higher levels of fear and anxiety in comparison to victims who endorse the idea of a benevolent world. 


\section{LIST OF PAPERS}

Andersson, M. Mellgren, C. (2015) Consequences of bias-motivated victimisation among Swedish university students with an immigrant or minority background. Irish Journal of Sociology, 24(2), pp. 226-250.

Andersson, M. Ivert, A-K. Mellgren, C. (2017) When there is more than one motive: a study on self-reported hate crime victimization among Swedish university students. International Review of Victimology, 24(1), pp. 67-81.

Andersson, M. Mellgren, C. Ivert, A-K. How victims conceptualize their experiences of hate crime. Awaiting review in Sage Open.

Andersson, M. Ivert, A-K. Mellgren, C. Does having friends with experiences of hate crime increase fear among women, sexual minorities, and Muslims? Manuscript.

I have written the introduction, background and discussion, formulated the questions and aim, and conducted the statistical and/or qualitative analysis for each article. My supervisors, Caroline Mellgren and Anna-Karin Ivert, have continually given me feedback and suggested development in both form and content. The regression analysis in Andersson \& Mellgren (2015) was conducted in consultation with supervisor Caroline Mellgren, and the group categories for the regression analysis in Andersson, Ivert \& Mellgren (2017) was developed in consultation with Anna-Karin Ivert. 


\section{INTRODUCTION}

When I meet new people and they find out that I do research on hate crime victimization, most say: "What an important topic!". Then they often look a bit puzzled and ask: "What exactly is hate crime?". I think that this reaction says a lot about the label "hate crime".

Putting the word "hate" in conjunction with "crime" gives weight to the label and seems to provide information about the dimensions of these acts (Jeaness \& Grattet 2001). At the same time, it is a label without evident content. Other labels have been suggested as replacements, for example "bias-crime" or "prejudice-based crime", in order to avoid misinterpretations (for a discussion on these labels, see Iganski 2008). These replacement labels have, however, gained less ground than the label hate crime. For better or worse, it appears as if though the label hate crime will persist well into the future within science, politics, law and activism alike, despite its many limitations.

Acknowledging the persistence of the term hate crime does not resolve the problem of its vague content. It is my belief that a useful field definition of hate crime should also work across cultural contexts by identifying core elements. I have been influenced and guided by Perry's (2001) definition of hate crime, a definition that has made a lasting imprint on the field of hate crime studies;

Hate crime, then, involves acts of violence and intimidation, usually directed toward already stigmatized and marginalized groups. As such, it is a mechanism of power and oppression, intended to reaffirm the precarious hierarchies that characterize a given social order. It attempts to re-create simultaneously the threatened (real or perceived) 
hegemony of the perpetrator's group and the "appropriate" subordinate identity of the victim's group. It is a way of marking both the Self and the Other in such a way as to reestablish their "proper" relative positions, as given and reproduced by broader ideological patterns of social and political inequality. (Perry 2001:10)

The emphasis on structure and identity in this definition has been criticized and simultaneously acknowledged. Most scholars concur in the understanding of hate crime as part of a structural power dynamic, but many call for a more complex understanding of the interplay of different group belongings and the role played by situational risk factors in hate crime causation (see for example Iganski 2008 and Chakraborti 2015).

During the process of designing the research project on which Articles 1-4 is based, I and my co-authors Caroline Mellgren and Anna-Karin Ivert have tried to synthesize these different approaches into an operationalization that has both national and international relevance, and that takes structural and situational factors into account. In the project, we examine experiences of hate crime among students at Malmö university by conducting a combined survey and interview study.

\section{Aim}

Hate crime studies is a young field in which in theoretical propositions or conclusions drawn in a single or a few studies have a large impact. My aim is to make a twofold contribution to the field by 1) examining field assumptions and 2) developing theory on causes and consequences of hate crime.

The examination of field assumptions takes place in Articles 1-4 of the present dissertation. An overview of the assumptions examined in each article is summarized in Table 1 . The theory development takes place in Chapters 3 and 6 of the present dissertation. 
Table 1. Assumptions and knowledge gaps examined in Articles 1-4

Article 1 Assumption: Hate crime victimization result in higher levels of fear of crime in comparison to non-bias crime

Article 2 Assumption: Police reporting is lower among victims of hate crime that target more than one identity category

Article 3 Assumption: Hate crime targets the self of victims

Article 4 Assumption: Hate crime instils fear beyond the initial victim 


\section{BACKGROUND}

\section{Chapter outline}

In the following chapter, I will focus on hate crime in a Swedish context. In Articles 1-4 (see chapters 4 and 5), I primarily summarize international research, and the local context is only briefly described. Therefore, the following chapter provides a detailed account of the local and political context ${ }^{1}$.

The chapter begins with a summary of the narratives present in the Swedish policy domain with regard to hate crime. The policy domain here refers to "components of the political system organized around substantive issues", (defined by Best (1987) and cited in Jeaness \& Grattet 2001:6). In this part of the background, I present the narratives used to describe hate crime in the official reports of the Swedish government, legal propositions, and reports from the National Council for Crime Prevention, the National Police Authority and the Prosecution Authority.

The presentation is followed by an overview of the official hate crime statistics in Sweden, and the chapter ends with a review of empirical research on hate crime victimization in a Swedish context.

\section{Hate crime narratives in the Swedish policy domain}

The introduction of what is now referred to as hate crime legislation in Sweden coincided with a legal reform aiming to increase procedural justice through a further development of mitigating and aggravating

1 For those interested in international reviews, I recommend Chakraborti \& Garland (2015) Responding to Hate Crime, Hall, Corb, Giannasi \& Grieve (2015) The Routledge International Handbook on Hate Crime, and Iganski \& Levin $(2015)^{a}$ Hate Crime: A Global Perspective. 
circumstances (for a summary, see SOU 2008:85). The legislative proposal was presented in 1993 (Prop. 1993/94:101) and a new penalty enhancement was proposed for crimes in the penal code insofar that

[...] the motive for the crime has been to violate a person, an ethnic group, or other group of persons, due to race, skin color, national or ethnic origin, confessions of faith or other similar circumstance. (Prop. 1993/94:101: 6).

The acts encompassed by the penalty enhancement were not referred to as hate crime in the proposition cited above, nor in the official report on racial discrimination that preceded it (SOU 1991:75, Prop. 1993/94:101). Instead, the acts were presented as part of right wing activity, propaganda, and racist sentiments (ibid.). The interpretation of hate crime as part right wing extremism is not unique; Iganski (2008) has observed the same tendency in Britain.

The factors behind the legal proposal and the official report that preceded it were critique directed at the Swedish justice system by the Committee on the Elimination of Racial Discrimination (CERD), and a rise in right wing extremism (Bunar 2007). According to the report from CERD, the Swedish state had failed to create a legal framework able to uphold the principles laid forth in the International Convention on the Elimination of All Forms of Racial Discrimination (ICERD). Apart from the suggestion of a penalty enhancement, the proposal also contained suggestions on how to reduce ethnic discrimination on the labor market and hate speech through new legislation, and thereby strengthen the full implementation of ICERD (SOU 1991:75, Prop. 1993/94:101).

The label hate crime first appears in an official report (SOU 2000:88) and a new legal proposal in the early 2000s (Prop. 2001/02:59), which lead up to the inclusion of sexual orientation as a category for protection. In both documents, the term hate crime is used when referring to the dissertation of Tiby (1999), who studied hate crime victimization among sexual minorities in Sweden. Her work is presented as an empirical foundation for the need to include sexual orientation due to the high level of victimization among sexual minority members (SOU 2000:88). Thereby, Tiby's dissertation (1999) had an evident impact on the language used to describe these forms of violence, since the framing of 
these acts as hate crimes in political documents on state level appear after the release of her dissertation and initially reference her work directly.

The official report (SOU 2000:88) and the legal proposal (Prop. 2001/02:59) connects right wing activities and racist sentiments with homophobia by presenting homophobia as part of the same symbolic and political narratives that encourage racism. Homophobic hate crime is consequently integrated into the previous model, explaining racially motivated hate crime as part of right wing extremism. The interpretation of homophobia as internal to racism is also present in the Swedish government's new strategic platform to counteract hate crime (Regeringskansliet 2016).

Moreover, hate crimes are presented as attacks on the democratic regime of governance as they are held to express 'complete disregard' for the principles of equality and freedom of all peoples laid forth in the Universal Declaration of Human Rights (SOU 2000:88, Regeringskansliet 2016). The penalty enhancement in the case of Sweden thereby appears to be the result of understanding these incidents as crimes against the state, rather than crimes against individuals and communities.

The policy domain in Sweden thereby differs greatly from the research presented by Jeaness and Grattet (2001) in which they examine the policy domain the United States. Jeaness and Grattet (2001) trace the penalty enhancement and the label hate crime to the activities of various civil rights movements, spearheaded by the anti-defamation league who collected and presented data on anti-semitic hate crime in order to gain ground for a penalty enhancement. Contrarily, in the case of Sweden, the penalty enhancement is introduced as a response to international criticism (SOU 1991:75, Prop. 1993/94:101), and the label hate crime gained ground in an academic context prior to its use to describe biasmotivated crime in a political context.

The legal proposals and official reports on hate crime are characterized by an absence of descriptions regarding the harms done to direct victims and their communities. Internationally, it seems to be more common to motivate penalty enhancements for hate crime through the principle of proportionality, as a growing body of research suggests that hate crime causes greater harm to victims in comparison to equivalent crimes without such a motive (for a discussion, see Iganski \& Lagou $2015^{\mathrm{b}}$ ). 
In 2013, the National Police Board published an inspection of the capacity of the police department to identify and investigate hate crime. The core problems identified were the following: 1) the lack of a coherent definition of hate crime between the Police Authority, National Council for Crime Prevention (BR ) and the Prosecution Authority creates problems in the prosecution chain; 2) departments that lack explicit policies regarding hate crime do not prioritize the identification and prosecution of such cases; 3 ) the lack of clear guidelines in how a suspected hate crime motive is registered in the report system creates problems in the reliability of the system (Rikspolisstyrelsen 2013). However, the investigation also showed that in many police regions, educational efforts had already been initiated or were planned to take place during 2013. In their recommendation, the National Police Authority concludes that there is a need for clear strategic directions, the presence of competence among staff, and a well-operating reporting system (ibid.).

Because of the inconsistent interpretation of the label hate crime between these key actors within the justice system, the Swedish government handed the National Police Authority the task of reaching an agreement of a unified and coherent definition together with the Prosecution Agency and BRA (Polisen 2015). The result was an agreement to define hate crime as acts encompassed by the penalty enhancement, including incidents with transphobic motives though not literally stated, along with unlawful discrimination and hate speech (ibid.). Nevertheless, the Swedish Council on Legislation recently rejected a legal proposal suggesting the inclusion of gender identity and gender expression as categories for protection (Lagrådet 2017). The council motivated their rejection by arguing that transphobic hate crimes already fall under the scope of the present legislation. The council also criticized the choice to use open gender categories and thereby include hate crime directed towards cis-identified men and women ${ }^{1}$ (ibid.).

\footnotetext{
1 Cis. A prefix from latin meaning "on the same side", used to describe individuals who are not transgender and/or whose gender identity is culturally congruent with the legal sex assigned to them at birth.
} 


\section{Official hate crime statistics in Sweden}

The Swedish Security Service (SÄPO) and the National Council for Crime Prevention (BRA) have been the state-level actors collecting information on hate crime in Sweden.

The sections below begin with a presentation of the police report data presented by SÄPO and by BRÅ. It is followed by a summary of the selfreport data in The Swedish Crime Survey (SCS).

Table 2. Inclusion criteria for police reports, 1993-2016

\begin{tabular}{|c|c|c|}
\hline Years & Authority & Definition \\
\hline $1993-2001$ & SÄPO & Crimes motivated by xenophobia \\
\hline $2002-2005$ & SÄPO & $\begin{array}{l}\text { Crimes motivated by xenophobia, anti-Semitism or } \\
\text { homophobia }\end{array}$ \\
\hline 2006-2008 & $\mathrm{BR} \AA$ & $\begin{array}{l}\text { Crimes motivated by xenophobia, anti-Semitism, } \\
\text { homophobia or Islamophobia }\end{array}$ \\
\hline 2009-2017 & BRÅ & $\begin{array}{l}\text { Crimes motivated by negative bias towards the } \\
\text { perceived ethnical background, skin color, } \\
\text { nationality, religion, sexual orientation or } \\
\text { transgender status of the victim }\end{array}$ \\
\hline
\end{tabular}

It needs to be noted that the inclusion criteria used by SÄPO and BRA in the collection of police reports have undergone several major changes presented in Table 2. SÄPO mapped xenophobically motivated hate crime 1993-2001, and added crimes motivated by anti-Semitism and homophobia in 2002. In 2006, BRA added police reports with islamophobic motives to the categories selected by SÄPO (BRÅ 2006). The inclusion criteria underwent a final major change in 2009, when BRÅ began classifying police reports as hate crimes in cases where the crime appeared to be motivated by a negative bias toward the ethnical background, skin color, nationality, religion, sexual orientation, or transgender status of the victim. The statistics thereby began to include hate crime taking place between minorities, hate crime directed against majority groups by minority groups, anti-religious hate crime regardless of religion, and bi-phobic, hetero-phobic and transphobic crime (BR 
2009). These inclusion criteria are more congruent with the Swedish penalty enhancement which uses open categories.

Diagram 1. Police reported hate crime, collected by SÄPO 2000-2005

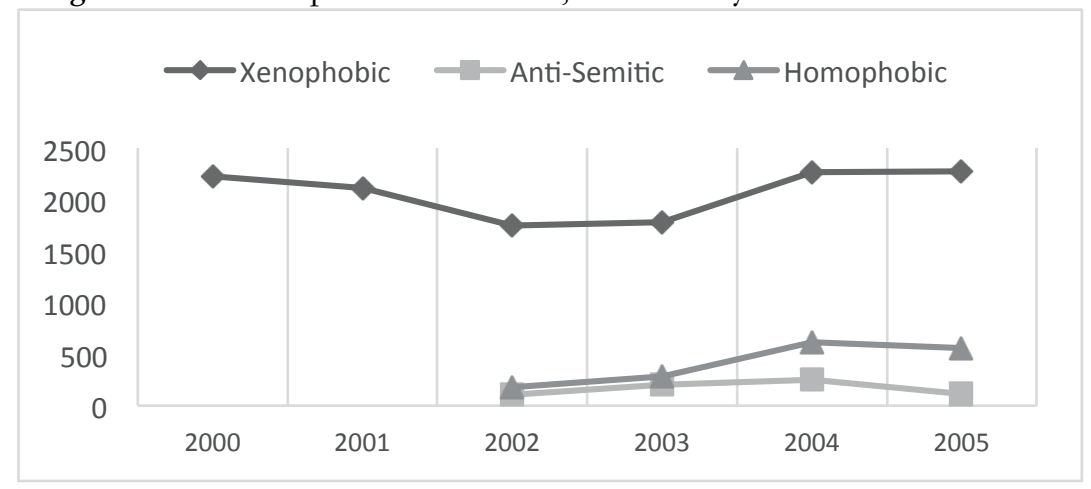

Diagram 2. Police reported hate crime collected by BRÅ 2006-2016
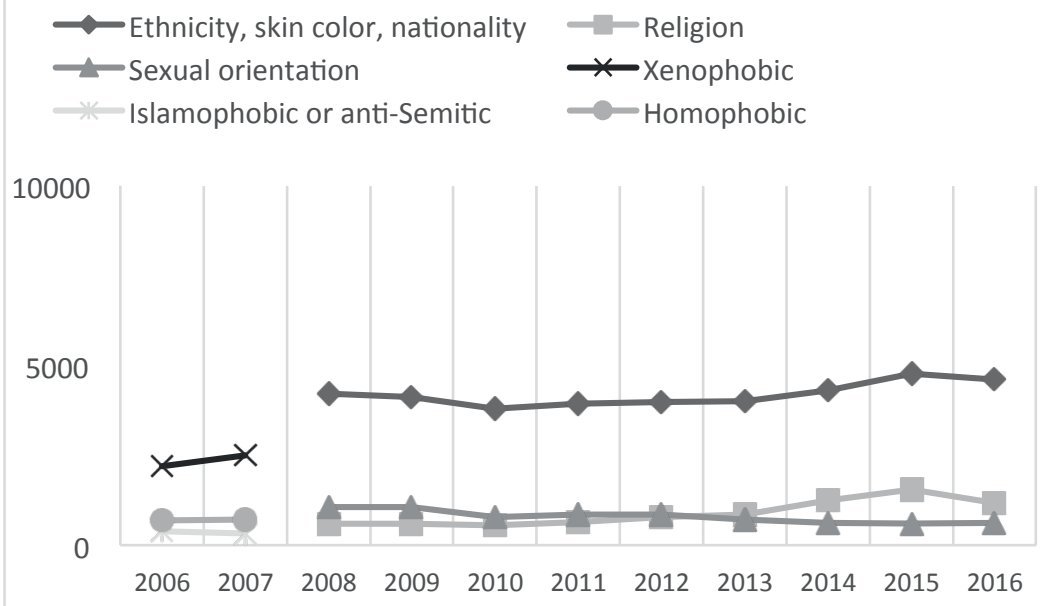

BRÅ (2006) has presented the data collected by SÄPO 2000-2005, summarized in Diagram 1. It is unclear whether the increase in xenophobic and homophobic hate crime in 2004 represent actual patterns of hate crime, changes in tendencies to report hate crime, or the methodological changes made in data collection in 2004 (ibid.). 
As shown in Diagram 2, the police reports collected by BR $\AA$ from 2006 to 2015 show an overall increase in the levels of reported hate crime targeting the ethnicity, skin color, nationality and religion of the victim, all of which reach the highest recorded levels in 2015. In contrast, police reports on hate crime targeting the sexual orientation of the victim appear more stable with a slight negative trend, with the highest documented levels in 2009 (BRÅ 2017).

The number of police reports nearly doubles in 2008 when BR revised the categories to be more congruent with the penalty enhancement. These figures show how changes in inclusion criteria have a profound impact on hate crime statistics.

Diagram 3. Self-reported hate crime in the SCS, 2007-2015

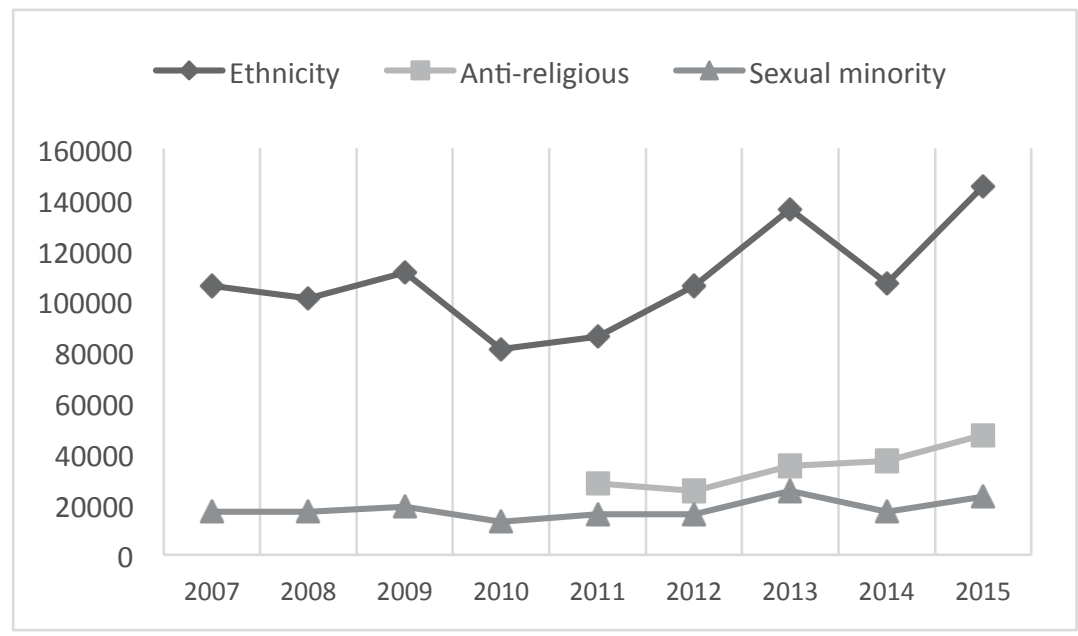

The self-report data presented in Diagram 3 is from SCS, and is based on a random population sample of 20000 individuals in the ages 16-79. The material is collected through phone interviews, and the response rate is approximately $60 \%$ in each wave. Self-reported hate crime in the SCS refers to robbery of person, assault, threat and harassment when perceived to be motivated by a negative bias towards the ethnicity or sexual minority status ${ }^{1}$ of the victim and has been presented since 2007 .

1 Refers to homosexual, bisexual and/or transsexual individuals, see BRÅ 2013 
Anti-religious hate crime has been included since 2011 (BR 2013 , BR 2009).

Self-reported hate crimes targeting the ethnicity of the victim fluctuates over time, while anti-religious hate crimes increase gradually. The levels of hate crimes targeting the sexual minority status of the victim have been largely stable since 2007 .

The same definition of anti-religious hate crime is used in the collection of police reports and the SCS. Since both the self-report data and police reports show a gradual increase, it can be assumed that there is an actual increase in hate crime victimization with this motive.

The other variables used in the official statistics in self-report and police report data on hate crime are not operationalized in the same way. The self-report data only includes hate crimes targeting the ethnicity of the victim, while the police report data also include skin color and nationality. Further, the victimization levels in the self-report data fluctuate in level, while the police report data show a gradually increasing trend. Similarly, the police reports on hate crimes targeting the victims due to their sexual orientation are decreasing, while the self-reported hate crimes targeting sexual minority status are stable, except for the peak in 2013. These discrepancies may be due to differences in operationalization but may also reflect actual differences between victimization rates and the tendency to report incidents to the police.

\section{Research on hate crime victimization in Sweden}

Most victim studies conducted in Sweden are focused on consequences of hate crime. In summary, these studies show that victims experience elevated levels of fear and worry post-victimization (Tiby 1999, Kalonaityté, Kawesa \& Tedros 2007, Ahlin \& Gäredal 2009, Wigerfelt, Wigerfelt \& Kiiskinen 2014, Wallengren \& Mellgren 2015, Wigerfelt \& Wigerfelt 2015, Wigerfelt \& Wigerfelt 2016, Wallengren \& Mellgren 2017), often take measures to hide their group belonging in order to avoid victimization (Tiby 1999, Wigerfelt $\&$ Wigerfelt 2015, Wallengren \& Mellgren 2017), and lose trust in key actors, such as the police (Wigerfelt, Wigerfelt \& Kiiskinen 2014, Wigerfelt \& Wigerfelt 2015, Wallengren \& Mellgren 2017).

Some studies bring up the presence of fear-inducers in victim communities (Wigerfelt, Wigerfelt \& Kiiskinen 2014, Wigerfelt \& 
Wigerfelt 2015, Wallengren \& Mellgren 2017). For example, the Wigerfelt, Wigerfelt and Kiiskinen (2014) interview study on afrophobic hate crime in Malmö showed that the participants experienced elevated levels of fear during the period prior to the arrest of Peter Mangs, a shooter who selected his victims on the basis of skin color. Mangs was sentenced for two murders and eight cases of attempted murder in 2012. The shootings have been described as evident message crimes, and many of the interview participants reported staying indoors after dark and covering windows as safety measures (Wigerfelt, Wigerfelt \& Kiiskinen 2014).

There are community-based variations in the behavioral strategies used to minimize victimization risk. For example, the tendency to hide group belonging is reported in studies on the LGBT community (Tiby 1999), the Jewish community (Wigerfelt \& Wigerfelt 2016), and the Roma community (Wigerfelt \& Wigerfelt 2015, Wallengren \& Mellgren 2015), but not in studies on the African-Swedish community (Kalonaityté, Kawesa \& Tedros 2007, Wigerfelt, Wigerfelt \& Kiiskinen 2014). This illustrates that the possibility to stay in the closet is a strategy primarily for those who are able to manipulate visible identity markers. Victims also report hiding identity markers strategically in contexts perceived to be particularly risky (Tiby 1999, Wallengren \& Mellgren 2015, Wigerfelt \& Wigerfelt 2015, Wigerfelt \& Wigerfelt 2016). For example, in the Wigerfelt and Wigerfelt (2016) study on anti-Semitic hate crime, the respondents explained how they would avoid wearing Jewish attire in the areas surrounding the synagogue in Malmö due to the high frequencies of anti-Semitic incidents occurring in these areas.

Wallengrens and Mellgrens $(2015,2017)$ two studies on anti-Roma hate crime also show how visibility varies in-group. The first study examined experiences of hate crime in the Traveler community in Gothenburg, a Roma group that has been present in Sweden for a long time. The second study examined experiences of hate crime among EU migrants ${ }^{1}$ who support themselves by begging. While members of the Traveler community were able to conceal their identity, the EU migrants did not have the same option. Moreover, the Travelers experienced hate crime as primarily caused by prejudice directed towards their ethnicity,

124 of 27 interview participants were Romani 
while the EU-migrants primarily perceived hate crime as caused by their social status as beggars (Wallengren \& Mellgren 2015, 2017).

Some of the studies present gender differences, with women being at higher risk for sexual harassment (Tiby 1999, Kalonaityté, Kawesa \& Tedros 2007, Gardell 2017, Wallengren \& Mellgren 2017). For example, the female participants in the Kalonaityté, Kawesa and Tedros (2007) study on afrophobic hate crime described extensive experiences of various forms of sexual harassment, ranging from being grabbed to being sexually exoticized and assumed to engage in sex work (Kalonaityté, Kawesa, Tedros 2007).

The prevalence of hate crime victimization varies between self-report studies. The highest victimization prevalence, $84 \%$, is recorded in a study of anti-Roma hate crime (Wallengren \& Mellgren 2015). The lowest recorded level, $13 \%$, is reported in a study on homophobic hate crime (Ahlin \& Gäredal 2009). It should be noted that there were large methodological differences between these studies; Wallengren and Mellgren (2015) studied lifetime prevalence in a snow-ball sample and used many victimization categories, while Ahlin \& Gäredal (2009) studied victimization during the past year in an online survey. Victimization levels in most studies land between 20 and 30 percent (Tiby 1999, Otterbeck \& Bevelander 2006, Wigerfelt, Wigerfelt \& Dahlstrand 2015).

Despite differences in method, target population, and definition of hate crime, the studies provide some indicators for victimization patterns on an aggregated level. Hate crime appears to be related to the visibility of the group belonging of the victim (Tiby 1999, Wallengren \& Mellgren 2015), and a normalization of prejudice and hate crime is presented in several studies (Tiby 1999, Kalonaityté, Kawesa \& Tedros 2007, Wallengrens \& Mellgren 2015, Wigerfelt \& Wigerfelt 2015). 


\section{THEORY}

\section{Chapter outline}

This chapter begins with an overview of theories about group conflicts from the perspectives of psychology, sociology, and intersectionality.

This overview is followed by a presentation of criminological theories on hate crime ${ }^{1}$; Perry's (2001) theory on hate crime as a form of doing difference, Chakraborti's and Garland's (2012) theory on the role of vulnerability in hate crime causation, and McDewitt's, Levin's and Bennet's (2002) hate crime typology. Thereafter, these theories on group conflicts and hate crime are integrated into a stratified ontology on causes of hate crime. The chapter ends with summary of theories on consequences of hate crime and victimization.

\section{Theoretical frameworks for understanding group conflicts}

\section{Psychological perspectives}

According to social dominance theory (SDT), discrimination ${ }^{2}$ and behavioral asymmetry ${ }^{3}$ on a group basis are governed by legitimizing myths and the individual tendency to endorse social dominance (Sidanius \& Pratto 1999).

Legitimizing myths refers to "attitudes, values, beliefs, stereotypes, and ideologies that provide moral and intellectual justification for the social practices that distribute social value within the social system" (Sidanius \& Pratto 1999:45). A legitimizing myth thereby justifies social practices. It is not hierarchy-enhancing by definition, as it may also be hierarchy-

1 For discussions on the applicability of classical criminological theories on hate crime, see Tiby 1999, Perry 2001, Walters 2011, Hall 2015 and Andersson 2016.

2 Includes institutional and individual discrimination

3 In-group favoritism, out-group favoritism, and self-debilitation 
attenuating. Moreover, conflicting myths over the same domain are common. For example, hierarchy enhancing sexism and hierarchy attenuating feminism both apply to the domain of gender.

Sidanius and Pratto (1999) hold that the presence of discrimination and hierarchy-enhancing legitimizing myths alone does not cause bias among all individuals equally. Instead, the tendency to discriminate or behave asymmetrically is mediated by the extent to which an individual desires, endorses and supports the notion of a group-based hierarchy based upon perceived group characteristics. Sidanius and Pratto (1999) have confirmed this proposition in 45 survey studies from various geographical contexts conducted between the years 1979 and 1996 (total $\mathrm{N}=18741$ ). Socially dominance-oriented individuals consistently reported identifying more strongly with arbitrary group identities, were likely to hold a high position in a social hierarchy, and have low empathy for others. However, individuals further down in a hierarchical system can be deeply invested in it and may therefore readily defend the same system that oppresses them (Sidanius \& Pratto 1999).

Connell (2017, first edition published 1995) provides a detailed account of how legitimizing myths and social dominance orientation coalesce with homophobia, transphobia, and misogyny. Connell (1999) uses trajectory analysis on interviews with men, primarily guided by psychoanalytical theory, to identify different pathways in masculine identity development and modelling.

Connell (2017) finds that the subordination of women unifies the masculine identity projects that she identifies in her study. She refers to the normative gender ideal of the participants as hegemonic masculinity. This is a form of masculinity that includes personal characteristics such as reason and intelligence, along with physical characteristics such as physical strength and prowess. The participants believed that these characteristics originated in the male biological sex, and therefore coded men as the natural leaders of public and private social relationships. Men who held these characteristics were given a position of natural dominance over women and men who lack these characteristics. Consequently, the ideal gender project for the men in Connell's (2017) study was social dominance-oriented (Sidanius \& Pratto 1999).

Connell (2017) holds that direct use of physical violence is the expression of masculinity projects in crisis, carried out by men who lack 
a core self. The following excerpt is from her research notes after an interview with one of the violent men in the study: "I have a sense of a false self system, an apparently rigid personality compliant to the demands of the milieu, behind which there is no organized character at all." (Connell 2017:111). She argues that although violence is part of any system of domination, there is no indication that a legitimate system would need violent practices to be sustained. Violence targets both women and men who transgress conservative gender norms, as such practices undermine the notion of group characteristics as bodily inherited (Connell 2017).

\section{Sociological perspectives}

Goffman (2011, first edition published 1963) uses the term stigmatization when referring to the process in which individuals are given subordinate positions in a social hierarchy. He identifies three main types of stigma: those associated to physical appearance, those associated to individual character, and those associated to tribal constructs. Stigmas associated with physical appearance are exemplified as disabilities, and testimonies regarding such forms of stigma constitutes the primary basis for his theory. Stigmas related to personal character are described as perceived character flaws, such as homosexuality, substance abuse, psychological ill-health, and the like. Lastly, stigmas associated with tribal constructs are related to some form of perceived heritage, exemplified by Goffman (2011) as religion and nationality. Goffman consequently (2011) holds that the stigma is social, and cannot readily be reduced to personal identity.

Moreover, the stigma tends to spread from the individual who holds it onto those who choose to associate with that individual. A common reaction among those without stigma, who Goffman (2011) refers to as "the normal", is therefore to avoid or reduce their contact with stigmatized individuals to a minimum. This appears to be the same process that Sidanius and Pratto (1999) refer to as in-group favoritism.

In similarity with Sidanius and Pratto (1999), Goffman's (2011) theory is a general theory that aims to explain the presence and consequences of stigma between a wide set of perceived group belongings. However, one key dynamic that remains overlooked by Sidanius and Pratto (1999) and Goffman (2011) is the role played by perceived transgressions as 
situational triggers of discrimination and violence. An early account for this theoretical branch is Blumer's brief article on race prejudice from 1958. Blumer (1958) claims that it is the content of the characterizations of racial groups that provides the source of prejudiced acts and intergroup conflicts:

\begin{abstract}
"The source of race prejudice lies in a felt challenge to this sense of group position. [...] Race prejudice is a defensive reaction to such challenging of the sense of group position. [...] It functions, however shortsightedly, to preserve the integrity and the position of the dominant group.” (Blumer, 1958:5)
\end{abstract}

A challenge of the position of a certain racial group can express itself in different ways: economic competition, challenge of privilege, challenge of social norms, expressions of superiority or defiance towards superiority, to mention a few (Blumer 1958).

\title{
Intersectional perspectives
}

A final theoretical approach that I want to present here is intersectionality. The branch of intersectionality that entered academia through Crenshaw (1991) originated from a critique within the women's rights movement. The critique was directed towards the tendency of the feminist movement to promote social issues primarily of relevance for straight, white, middle- and upper-class women (see for example Moraga \& Anzaldúa 2015, first edition published in 1981). In her article, Crenshaw (1991) presents several examples in which the American justice system fails to protect women of color from partner abuse, as the legal frameworks are formulated to meet the needs of white women. She argues that there is a need to recognize the presence of intersectionality, namely, the ways in which various group belongings come together to form living conditions and social relationships. Intersectionality thereby provides depth to the understanding of how group categories and hierarchies between groups coalesce. Since the publication of Crenshaw's (1991) article, intersectional critique has expanded from law into numerous fields, hate crime studies being one of them.

McCall (2005) conducted a review of how the problem of intersectional complexity - how group belongings interact - is tackled in 
empirical research guided by intersectional theory. McCall (2005) identifies three main approaches: the anticategorical approach, the intercategorical approach and the intracategorical approach. The anticategorical approach can be summarized as a rejection of group categories, and this branch of research primarily deconstructs the contents of group identities. Contrarily, established group categories are used strategically in the intercategorical approach, considering the "inequality among social groups and changing configurations of inequality along multiple and conflicting dimensions" (McCall 2005:1773). Lastly, the intracategorical approach usually deconstructs the contents and boundaries of overlapping group categories, while simultaneously acknowledging the persistence of some categories over time. The present dissertation is primarily methodologically based on an intercategorical approach to intersectional complexity.

\section{Criminological frameworks for understanding causes of hate crime}

Perry (2001) presents four institutions that co-create the preconditions which hold the potential to facilitate incidents of hate crime. These institutions are 1) labor, defined as the organization of work and education; 2) power, defined as "the ability to set the terms of discourse and action, and to impose a particular type of order" (Perry 2001:50); 3) sexuality, defined as the socially appropriate ways of forming relationships and gender; and lastly 4), culture, defined as the institution which assigns meaning to the roles and identities that we are ascribed or ascribe to ourselves (Perry 2001).

For Perry (2001), the conditions derived from these institutions co-create the ways in which we interact and construct our identities. The institutions also contribute to how we construct and do difference amongst one another by providing identity categories and attaching meaning onto markers of such identities. For Perry (2001) it is the acts of doing difference that occasionally express themselves as hate crimes. These incidents are understood as maintenance work for a social hierarchy:

In other words, hate-motivated violence is used to sustain the privilege of the dominant group, and to police the boundaries between groups by reminding the Other of his/her "place". (Perry 2001:55). 
Consequently, the Other is punished when they conform to negative and stereotypical expectations, but also if they transgress these expectations.

Chakraborti and Garland (2012) have criticized Perry (2001), arguing that the interpretation of hate crime as structural leads us to overlook its situational causes (Chakraborty \& Garland 2012). They acknowledge that norms, which are sometimes prejudiced, govern behavior and occasionally give rise to hate crime incidents. However, they also present other factors that can cause prejudiced behavior on a situational basis: 1) the inability to control language use and behavior when exposed to a stressor, 2) a subconscious experience of weakness and inadequacy which can cause individuals to overcompensate with externalized aggression, 3) fear of the unknown, and 4) the interpretation of the victim as a vulnerable and easy target. Vulnerability in Chakraboriti and Garland (2012) is, in line with Perry (2001) understood as being "different", for example through accent, skin color, clothing or culture.

Chakraborti and Garland (2012) stress the importance of an intersectional understanding of group belonging. They argue that separating group belongings from one another indicates a fundamental misunderstanding of the nature of how group belongings express themselves. They hold that group belongings interact with each other by co-producing risk- and protective factors in different environments. Chakraborti and Garland (2012) thereby ascribe a function to group belongings, rather than reducing them to categories or attributes.

One of the most frequently cited examples of a situational model for hate crime is the typology developed by McDewitt, Levin \& Bennet in 2002. The main purpose of their article was not to provide a theoretical account for the underlying causes of hate crime, but to build a typology to describe the situational triggers and expressions of hate crime based upon hate crime reports $(\mathrm{N}=167)$.

Firstly, McDewitt, Levin and Bennet (2002) identified hate crimes performed by thrill-seeking offenders, usually a group of young adults or teenagers seeking out their victims in places where minorities gather, such as gay clubs or religious sites. These incidents were in part related to a specific group dynamic in which the members of the offender group performed hate crime instrumentally to gain social status. They were also described as occasionally being founded on sadism. These incidents 
primarily center around humiliating the victim with threats, verbal harassment or minor assault.

Secondly, they identified hate crimes carried out by defensive offenders who perceived the victim as a threat to their community. These incidents mainly consisted of cases in which a family of color moves into a white neighborhood where they get harassed and/or have their property vandalized by one or more adult neighbors. The intended outcome for the offenders is to re-establish a hierarchy perceived to be under threat because the victims transgress perceived group boundaries.

Thirdly, McDewitt, Levin and Bennet (2002) identified a group of offenders that they describe as driven by retaliation. These incidents occurred in the aftermath of a majority-on-minority hate crime in order to satisfy a need for vengeance or justice, and were performed by vicarious victims. As such, these incidents express a rejection of and resistance to established hierarchies.

Lastly, they identified what they referred to as mission offenders. These offenders have a strong bias commitment, for example through engagement in white power movements, and act based on their political conviction. However, it should be noted that only one of the studied police reports fell into this category, making it an unusual form of hate crime.

The prerequisites, mechanisms and expressions of hate crime according to these different theoretical approaches are summarized in Table 3.

The only approach that contain information on all three of these aspects is Perry's (2001) theory. Chakraborti and Garland (2012) lacks description of the expressions of hate crime but presents prerequisites and mechanism, while McDewitt's, Levin's and Bennet's (2002) offender typology lacks prerequisites but contain mechanisms and expressions.

Different as Perry (2001) and Chakraborti and Garland (2012) might appear in Table 3, I would like to argue that these two perspectives are not mutually exclusive. Instead, I believe that the critique Chakraborti and Garland (2012) direct towards Perry (2001) is primarily a consequence of not recognizing that they are concerned with causes on different ontological levels. 
Table 3. Prerequisites, mechanisms and expressions of hate crime in different theoretical approaches

\begin{tabular}{|c|c|c|c|}
\hline Author & Prerequisite & Mechanism & Expression \\
\hline $\begin{array}{l}\text { Perry } \\
(2001)\end{array}$ & $\begin{array}{l}\text { Structural } \\
\text { hierarchy } \\
\text { formed by } \\
\text { institutions }\end{array}$ & Othering & $\begin{array}{l}\text { Doing } \\
\text { difference through } \\
\text { violence and/or } \\
\text { intimidation }\end{array}$ \\
\hline \multirow{4}{*}{$\begin{array}{l}\text { Chakraborti } \\
\text { and } \\
\text { Garland } \\
(2012)\end{array}$} & $\begin{array}{l}\text { Lack of self- } \\
\text { control }\end{array}$ & Stressor & \\
\hline & Insecurity & Identity building & \\
\hline & $\begin{array}{l}\text { Fear of the } \\
\text { unknown }\end{array}$ & Defense & \\
\hline & $\begin{array}{l}\text { Vulnerable } \\
\text { victim }\end{array}$ & Opportunity & \\
\hline \multirow{4}{*}{$\begin{array}{l}\text { McDewitt, } \\
\text { Levin \& } \\
\text { Bennet } \\
(2002)\end{array}$} & & $\begin{array}{l}\text { Group-dynamic } \\
\text { and sadism } \\
\text { (thrill) }\end{array}$ & Humiliation \\
\hline & & $\begin{array}{l}\text { Provocation } \\
\text { (defensive) }\end{array}$ & $\begin{array}{l}\text { Hierarchy } \\
\text { enforcement }\end{array}$ \\
\hline & & $\begin{array}{l}\text { Vengeance } \\
\text { (retaliation) }\end{array}$ & $\begin{array}{l}\text { Hierarchy } \\
\text { rejection }\end{array}$ \\
\hline & & $\begin{array}{l}\text { Ideological } \\
\text { conviction } \\
\text { (mission) }\end{array}$ & $\begin{array}{l}\text { Political } \\
\text { extremism }\end{array}$ \\
\hline
\end{tabular}

Perry (2001) does not propose that hate crimes are not mediated by situational factors; she explicitly mentions norm-breaking as potential triggers. However, situational triggers are not the factors that Perry (2001) primarily engages in discussion about. Her main concern is the link between institutions, identity-projects, and hate crime. Chakraborti and Garland (2012) on the other hand are concerned with situational factors that trigger hate crime incidents. However, without a proper ground for understanding what is at work in hate crime, Chakraborti's and Garland's (2012) approach encounters problems. The latter is most clearly manifested in that their core concept, perceived vulnerability, remains loosely defined. 
In Chakraborti's and Garland's (2012) theoretical approach, "vulnerability" becomes every factor that inhibits resilience to hate crime, without any explanations of why the factor in question yields such a function. However, when taking Perry's (2001) structural theory into account, we can propose that a factor that results in situational vulnerability should do so because of the association between that factor and stigma.

The sole prerequisite lifted by Chakraborti and Garland (2012) that does not align with the ontology proposed by Perry (2001) is the lack of self-control. The way in which a person with a lack of self-control responds to a stressor can be influenced by a social hierarchy. It is unlikely, however, that the social hierarchy is the cause low self-control (for an extended discussion on the development of low self-control, see Moffitt, Caspi, Rutter \& Silva 2006, first edition published in 2001).

The typology of McDewitt, Levin and Bennet (2002) offers insight on the variations in how hate crime and doing difference (Perry 2001) can express itself. Parallels can also be drawn between the typology and Chakraborti's and Garland's (2012) theory of vulnerability. The thrillseeking offenders can be understood as acting on psychological insecurity, and defensive offenders can be understood to act on fear of the unknown. However, there are also some differences. The mission offenders, the retaliatory offenders, and the defensive offenders do not seem to perceive their victims as vulnerable; instead, they appear to perceive their victims as a form of threat. Moreover, none of the offender groups in the typology appears to act on pure situational impulse.

It needs to be noted that the external validity of the typology has been questioned by Phillips (2009) who found that its application in the New Jersey county was limited. However, local and temporal variations in typological expression are to be expected since the expression of hate crime vary across cultural contexts and over time (for an overview, see Iganski \& Levin $2015^{\mathrm{b}}$ ).

\section{An integrated approach to hate crime causation}

As described in the introduction, one aim for the present dissertation has been to develop theoretical frameworks for hate crime causation. On the following pages, I integrate the previously presented theoretical frameworks regarding group conflicts and hate crime into a model. 
According to the theories presented in this chapter, hate crime incidents appear to emerge in the conjunction between inherited social hierarchies and the individual responses to said hierarchies. In critical theory, conjunctionally constituted phenomena are held to be based on what is referred to as a stratified ontology (Bhaskar 2005, first edition published 1979). The concept of a stratified ontology can be exemplified in the relationship between psychology and neurology. Psychology presupposes the presence of neurology. However, psychology is not reducible to neurology but constitutes a phenomenon of its own. Similarly, hate crime presupposes the presence of group conflicts, but cannot readily be reduced to it. Below, I present a brief sketch of how a stratified ontology for hate crime could be constructed based on the theories previously presented in this chapter.

A first stratum of relevance for understanding hate crime causation is group identity. Group identities are constructed arbitrarily, based on the perception of certain individual characteristics as unevenly distributed between individuals via group belonging (Blumer 1958, Sidanius \& Pratto 1999, Perry 2001, Goffman 2011, Connell 2017). The latter results in the belief that groups are innately different, though the content of group characteristics and perceived groups tends to vary over time.

A second stratum could be referred to as hierarchy. Hierarchy assigns value to groups based on their perceived characteristics. Hierarchy thereby provides advantages to some groups, and disadvantages to other groups. Advantages are often referred to as privilege, while disadvantage is often referred to as stigma (Sidanius \& Pratto 1991, Perry 2001, Goffman 2011). Stigma can result in the perception of individuals belonging to certain groups as particularly dangerous and/or vulnerable (Blumer 1958, Goffman 2011, Chakraborti \& Garland 2012). Moreover, hierarchy also leads to feelings of entitlement among privileged groups, following the belief that some groups are inherently suited for leadership and innovation while other groups are inherently suited for low-skilled work and servitude (Blumer 1958, Perry 2001, Connell 2017).

A third stratum can be referred to using Perrys (2001) concept of doing difference, which is one of many ways that individuals can respond to the presence of a hierarchy (Blumer 1958, Sidanius \& Pratto 1999, Perry 2001, Connell 2017). Here, doing difference refers to acts that strengthen group identities by reaffirming perceived group differences (Perry 2001). 
Most practices of doing difference are habit-based and manifest in every day interactions between individuals, and are supported by social norms and institutions (Blumer 1958, Sidanius \& Pratto 1999, Perry 2001, Goffman 2011, Connell 2017).

Model 1. A stratified ontology of hate crime

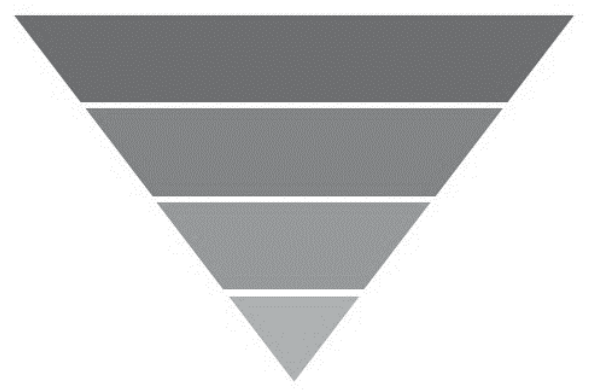

Strata 1: Group identity

Strata 2: Hierarchy

Strata 3: Doing difference

Stata 4: Hate crime

The fourth and final stratum presented here is hate crime, defined as practices of doing difference when expressed through violence, intimidation, and/or threats thereof. Hate crime can be triggered by perceived provocations (Blumer 1958, Sidanius \& Pratto 1999, Perry 2001, McDewitt, Levin \& Bennet 2002, Chakraborti \& Garland 2012, Connell 2017), or by opportunity (Iganski 2008, Chakraborti \& Garland 2012). In some cases, they also appear to be premeditated (McDewitt, Levin \& Bennet 2002). Those who perform hate-based violence appear to have a poorly developed core self (Connell 2017, Chakraborti \& Garland 2012), and endorse the existence of group-based hierarchies (Sidanius \& Pratto 1999, Perry 2001).

\section{Theoretical frameworks for understanding consequences of hate crime}

The final pages of this chapter contain an overview of theoretical frameworks of consequences of hate crime and trauma.

A growing body of research has come to support the notion that hate crime causes greater harm to victims in comparison to non-bias crime (Herek, Gillis \& Cogan 1999, McDewitt, Balboni, Garcia \& Gu 2001, 
Smith, Lader, Hoare \& Lau 2012, Pezzella \& Fetzer 2017). It has been argued that this is because hate crime targets the self of the victim, and that the negative impact has a particularly detrimental aspect when combined with social stigma (Perry 2001, Iganski 2001, Lawrence 2006). According to Goffman (2011), stigma usually becomes visible through the presence of symbols, which can be connected to physical appearance or behavior. Some stigmas are non-visible and remain undisclosed unless the individual chooses to inform their social group. It should be noted that non-visible stigma does not result in an absence of stigmatization. In Goffman's (2011) work, there are several testimonies from individuals who suffer greatly when exposed to ridicule, disgust, and resentment directed at their stigma by unknowing members of their social group. The pain of such isolation causes most individuals with non-visible stigma to "come out", despite the risk of social rejection (Goffman 2011).

Goffman (2011) also maintains that individuals under stigma are not perceived as fully human, and that this dehumanization serves as the basis for discriminatory actions. According to Goffman (2011), discriminatory actions are often unintentional yet highly effective in reducing the opportunities and living conditions of stigmatized groups.

However, the theoretical works cited above do not fully account for the reason why an incident that targets the identity of the victim causes greater harm, or why the presence of stigma and dehumanization is particularly detrimental to victims. In Herman's (2015) work on trauma, we can find further theoretical guidance for advancing and contextualizing consequences of hate crime.

Herman (2015) holds that trauma primarily originates from the feelings of powerlessness during the incident in question, along with the undermining of trust between the individual and their social context. The undermining of trust can occur in relation to society, community, or family, depending on the relationship between the victim and the offender. Consequently, trauma is primarily to be understood as a state of objectification and isolation. It results in physical and psychological over-tension, which apart from its physiological symptoms, manifests in high levels of anxiety and suspicion towards other people. Some also experience flashbacks due to their trauma and are highly sensitive to settings that resemble the one in which they were traumatized. As a result, the individual tends to develop strategies to handle everyday 
activities that might trigger stressful memories. Lastly, some victims respond to trauma by dissociation, a reaction in which the individual becomes emotionally numb and loses contact with their feelings.

If the individual does not regain their status as subject and/or break the emotional isolation caused by the trauma, they risk losing their sense of self. The latter is observable in a breakdown of the integrity of the victim. It can manifest as an inability to identify dangerous settings, difficulty to distinguish their own boundaries and feelings from those of others, and/or practices of self-harm. Moreover, Herman (2015) distinguishes between Type I and Type II traumas. Type I refers to trauma based on one incident, and Type II refers to trauma caused by repeated incidents taking place over a prolonged period of time.

In light of Herman's (2015) theory, I maintain that hate crimes have a negative impact on victims since they reduce the victim to an object. They do so by targeting a negative stereotype associated with units for social categorization that are beyond the control of the victim, such as their gender, race, ethnicity, sexual orientation or religion. This leaves the victim in a state of powerlessness, described by Herman (2015) as one of the two factors behind trauma. Further, the reduction to a negative stereotype separates the victim from society, thereby activating the second factor in Herman's (2015) model for trauma: the undermining of trust between the individual and their social context. The latter should be more prominent among victims who belong to groups subjected to social stigma, as the prejudice expressed by the offender is held by a larger collective and often normalized in media (Perry 2001, Goffman 2011).

Indeed, many victims of hate crime develop strategies to reduce the risk of future victimization (see Chapter 2). These strategies can be interpreted as attempts to rebuild agency and thereby reduce the feelings of powerlessness that fuel a trauma. However, these strategies tend to focus on reducing visibility of the identity marker that was targeted during the incident (ibid.). Such strategies do not necessarily resolve the emotional harm done by the offender but can turn it into a continuum in which the victim perpetuates the stigma expressed by the offender during the hate crime incident. In line with Chahal (2017), I therefore maintain that constructive healing among hate crime victims is based on the validation of the wrongs made by the offender, along with the strengthening of the sense of self and agency of the victim. 
Hate crimes are also held to instigate harm beyond the individual victim. They signal threat to all individuals who share the same identity marker that was targeted during the incident, which is why hate crimes have sometimes been theoretically framed as message crimes, with an in terrorem effect on vicarious victims (Weinstein 1991, Perry 2001, Iganski 2001, Noelle 2002, Perry \& Alvi 2011, Bell \& Perry 2015). The in terrorem effect is believed to cause vicarious victims to have an emotional reaction equivalent or similar to that of direct victims and is conveyed through social networks as well as media (Weinstein 1991, Perry 2001, Iganski 2001, Noelle 2002, Perry \& Alvi 2011, Bell \& Perry 2015).

Noelle (2002) has used Assumptive World Theory to further explain and make propositions about the in terrorem effect. According to Assumptive World Theory (Janoff-Bulman 1989), all individuals develop postulates of an assumptive world based on lived experiences. Perceived benevolence of the world is a widespread postulate, defined as the belief in an inherent goodness of the world and other people. As a result, traumatic events cause cognitive incongruence: "In the case of traumatic negative events, individuals confront very salient, critical 'anomalous data', for the victimization cannot be readily accounted for the person's existing assumptions.” (Janoff-Bulman 1989:121). Noelle (2002) identifies the same cognitive conflict among vicarious victims of hate crime and find that they attempt to defend their belief of existing in a benevolent world by attributing responsibility to the behavior or character of the victim. In the cases where the belief in a benevolent world was rejected, vicarious victims described a heightened sense of vulnerability and fear of future victimization (Noelle 2002).

In sum, it is established that hate crime has negative impacts on direct victims, and there are indicators that hate crime, by signaling threat, also has a negative impact on larger communities. 


\section{METHOD}

\section{Chapter outline}

The following chapter begins with a presentation of the methodological choices made when designing the study on which this dissertation is based, coupled with the knowledge gaps these were intended to fill. The presentation is followed by a summary of the data collection, and ends with a summary of the ethical considerations and choices made in relation to data collection.

\section{Meeting knowledge needs}

Experiences and Exposure to Hate Crime (EEHC) was planned during the spring of 2013. The study was methodologically designed by Caroline Mellgren and myself to offer insight into a few of the many empirical gaps within the field of hate crime studies.

The research at hand in 2013 indicated the presence of a normalization of hate crime among minorities; African-Swedish individuals described how they expected to be subjected to various forms of racism (Kalonaityté, Kawesa, Tedros 2007), and sexual minorities systematically hid their identities in fear of victimization (Tiby 1999).

We regarded the lack of studies including more than one specific target group as problematic, as the need for inter-group comparisons had been expressed (Triffleman \& Pole 2010). Most of the studies conducted in Sweden only included victims; the lack of a base-line or control group made the results, such as elevated levels of fear, difficult to contextualize. In 2013, the only exceptions from this pattern were two studies that examined experiences of hate crime among sexual minorities (Tiby 1999, Ahlin \& Gäredal 2009), comparing victims with non-victims. 
Consequently, we wanted to design a study that would allow us to compare victimization patterns between hate crime with different motives. Furthermore, we wanted to have two different control groups: victims with experiences of non-bias crime, and non-victims.

The difficulties of attaining methodological validity in hate crime studies had been expressed in a Swedish context (Tiby 2007). Tiby (2007) argued that hate crime is often filtered through many actors, such as researchers, victims, offenders, police officers and/or prosecutors. Studies using such different samples may be studies on different forms of victimization altogether. Self-report studies were becoming increasingly common, but little was known about why individuals report incidents as based on prejudice (ibid.).

Consequently, Caroline Mellgren and I wanted to design a study primarily centered on the experiences and interpretations of victims. We chose to use self-report data and categorize incidents that the victims had interpreted as motivated by prejudice as hate crime. We decided on a mixed method design, in which survey and interview data would complement each other. The survey study would provide information about victimization patterns and allow us to study the relationship between hate crime victimization, fear of crime and worry. The interview study would provide more detailed information about hate crime; the meaning-making attached to these incidents, and the consequences experienced by victims.

Lastly, an inventory of ongoing research on hate crime in Sweden showed a movement from researching risk groups to examining hate crime in various stages of life. One of these studies examined hate crime in upper secondary school, and the other focused on anti-Semitic hate crime on the labor market. There was, however, no ongoing research on experiences of hate crime among university students. Furthermore, a review of international research showed that university students appeared to be at high risk for hate crime victimization, negatively impacting the overall health and study performance of the victims (for a recent review, see Michaels 2015).

With this background, we deemed it scientifically motivated to study hate crime victimization in a sample of Swedish university students. Studying hate crime in such a population would 1) complement the knowledge produced by the two ongoing projects on hate crime in 
different stages of life, 2) provide the possibility to examine hate crime victimization with various motives, and lastly 3) include the control groups we wanted in the survey study.

\section{Group categories included in the study}

Firstly, we chose to include the identity categories studied by BRA in their collection of police reports for reasons of comparability and local political relevance (origin/background, religion, sexual orientation).

Secondly, at the stage of study design, I was in contact with Dr. Lucy Michaels (presently working at Ulster University) who had analyzed the results of a self-report study on hate crime victimization among university students in Britain. She recommended us to include sex and gender as categories. She had found strong indicators in the open answers of the participants that sex and gender influenced the expressions of hate crime, and she suspected that a large group of students had been targeted due to their sex and/or gender alone.

Debate concerning the inclusion of sex and/or gender as categories for protection under Swedish legislation was non-existent in 2013 when the study was designed ${ }^{1}$. Further, a quantitative study had shown that hate crime targeting women due to their sex and/or gender were more frequent than racially motivated hate crime (Perry 2012). It was, and remains, my belief that these aspects along with the observations made by Dr. Michaels pointed to the need for examining this category of hate crime.

Thirdly, we also chose to include disability as a category in the study. As with sex and/or gender, there was no political debate in Sweden concerning the inclusion of ableism under hate crime legislation ${ }^{2}$. At the same time, international research had identified, and continues to identify, individuals with disabilities as particularly vulnerable to hate crime (for an overview, see Roulstone \& Mason-Bish 2013).

Victimization questions were based on descriptions of acts rather than crime labels. The latter is common in victim studies since participants tend to under-report their experiences of victimization if crime labels are used due to the symbolic value embedded in the labels. Types of victimization included in the EECH are experiences of harassment (verbal

1 Has been lifted more recently, see Granström (2016), Mellgren, Brax and Bladini (2017) and Soares (2017). 2 Has been lifted more recently, see Isaksson (2018). 
or written threats, harassment or bullying), minor assault or non-verbal threats (having been followed or chased, hit with an open hand, had one's hair pulled or similar), assault or aggravated assault (having been hit with a closed fist, kicked or attacked with a weapon or an object), sexual harassment (unwanted sexual acts, such as touching, kissing, grabbing or fondling), rape (rape and/or having been forced to have sex), and property crime (robbery or burglary). For a discussion regarding the selection of acts and the categorization of these as crime, see Andersson and Mellgren 2016.

The formulation used to distinguish hate crime from non-bias crime in the questionnaire was: "Do you believe that the incident/incidents may have been motivated by prejudice against your sex, religion, gender identity, sexual orientation, origin/backgound or disability?", which followed each victimization question. The participants who answered "yes" were further asked to specify which form/forms of prejudice they percieved to have motivated the incident/incidents, and these incidents were categorized as hate crime.

\section{Data collection}

The survey study was modeled on a previous study conducted by Perry (2012), which examined hate crime victimization among Canadian students. In Perry's (2012) study, the questionnaires were distributed and answered in classrooms, a methodological approach that resulted in an unusually high response rate.

According to the numbers presented by Malmö University, approximately 22000 students were registered annually in 2013. Therefore, we initially planned to randomly select one third of the courses, estimated to comprise approximately 7000 students. However, when asked to receive registry data we realized that term "registered students" refers to the number of registrations rather than the number of individuals. Therefore, we counted the number of students and study participants in each classroom instead of relying on the figures of registered students. When we encountered students who had participated at an earlier time, they were excluded from participating again.

Furthermore, we were not always able to provide the students with the opportunity to answer the questionnaire at scheduled hours as initially planned. Some teachers felt that they were unable to provide tuition time 
for the study. They declined when we offered to schedule and pay for the classroom for an extra hour, citing the need for administration on their behalf. Consequently, we sometimes offered students the possibility to stay and answer the questionnaire after lectures or provided them with the alternative of bringing a questionnaire home, along with a stamped envelope, depending on the practical circumstances.

We were given permission to distribute questionnaires to 264 of the 277 classes in our original sample. Two of these classes had been cancelled, and we refrained from distributing questionnaires in a third class one since one of the students had recently and unexpectedly passed away. In this case, the teacher feared the questionnaire would stir up grief and other strong emotions among the students. In most cases, however, we could not find a proper date for distribution of questionnaires due to lack of scheduled tuition. The latter happened primarily in courses in which students were writing their thesis and all tuition was individualized through the supervisors. Lastly, there was one case in which the responsible teacher refused to answer emails or meet with the research team in person.

We met 4649 individual students in total, of whom 2853 chose to participate in the study, corresponding to a response rate of $61 \%$. The participation rate varied depending on the distribution method; $80 \%$ of those given the possibility to answer the questionnaire in class participated as well as $29 \%$ of those receiving questionnaires in stamped envelopes.

A total of 574 participants $(20 \%)$ reported experiences of hate crime targeting their sex and/or gender, origin/cultural background, religion, sexual orientation and/or disability. The frequencies are presented in Table 4. It should be noted that 133 of the participants with experiences of hate crime had been targeted due to more than one group belonging, which is why the total does not correspond to the sum of victims in each motive.

Participants in the interview study were recruited through the survey study. The students were able to read about an upcoming interview study about hate crime victimization on the last page of the questionnaire, and could submit their contact information if they wanted to participate. The interview study was aimed at hate crime victims. 
A total of 32 individuals were interviewed. Two of the interviews were excluded because they had no direct experiences of hate crime targeting themselves, but had stories about close friends or relatives who had been victimized. Another two interviews were excluded because their definition of hate crime fell outside of the definition used in the study. One had been targeted due to his political engagement in feminist questions. The other person described two incidents during which he had been dehumanized, but the dehumanization process did not originate in group belonging. An overview of the motives is presented in Table 5 .

Table 4. Hate crime victimization in the survey

\begin{tabular}{|ll|}
\hline Motive & Respondents \\
\hline Sex and/or gender & 402 \\
\hline Origin/cultural background & 182 \\
\hline Religion & 67 \\
\hline Sexual orientation & 50 \\
\hline Disability & 20 \\
\hline Total & 574 \\
\hline
\end{tabular}

Table 5: Interview participants

\begin{tabular}{|ll|}
\hline Motive & Respondents \\
\hline Sex and/or gender & $16(4)$ \\
\hline Origin/cultural background & 15 \\
\hline Sexual orientation & 8 \\
\hline Religion & $4(1)$ \\
\hline Disability & 3 \\
\hline Total & 28 \\
\hline
\end{tabular}

Most of the interview participants (18) had experiences of hate crime with more than one motive. Four of the participants had experiences of incidents that were gendered but did not refer to them as such. For example, one participant described an incident during which the offender shouted "Go home, whore!". The participant referred to the incident as racist, but not as targeting her sex or gender. In this case, however, 
misogyny plays a central role, which is why it is presented in a parenthesis in Table 5 along with three other similar cases.

\section{Ethical considerations}

Swedish legislation on research ethics combines deontological and consequentialist principles. Research containing sensitive information ${ }^{1}$ must be tried and approved by an ethic review board. As a rule, research containing sensitive information is directly prohibited by law unless participation is voluntary and there are explicit knowledge gains. Moreover, research will not be approved by an ethical board if there is an alternative procedure that is less intrusive to the individual integrity of the participants and could provide equal knowledge gains.

EEHC was approved by the regional ethical review board in Lund (DNR 2013/221). The following pages contain a summary of the ethical considerations made during the planning and execution of the project. The summary is not exhaustive, but captures the core values and central ethical problems and choices made prior to and during the research process.

The student health service was contacted prior to the distribution of questionnaires. The staff was briefly educated in the consequences of hate crime victimization and provided with information about the study.

Prior to distribution, we provided all teachers with a brief description of the study and encouraged them to publish it on the student's digital learning platform a few days before the data collection.

Upon distribution, all students 1) received an oral summary of the aim of the study and content of the questionnaire, 2) were informed that participation was voluntary, 3) were informed that consent could be withdrawn at any time, and 4) received a folder containing contact information to the student health services and victim support groups. General information about the study and hate crime was added to the folder, so that victims who would choose to bring one home would not be singled out.

The questionnaire came in five different versions in which the content was the same, but the questions appeared in a different order. This prohibited fellow participants from drawing conclusions about each

1 Sensitive information includes race or ethnic origin, political opinion, religious or philosophical beliefs, union membership, and information regarding health or sexuality (SFS 2003:460 3\$) 
other's experiences by observing which parts of the questionnaire a fellow student answered. Further, the questionnaire also contained a set questions solely directed towards those who had no victimization experiences. The latter prohibited students from drawing conclusions about each other's victimization experiences based on the time spent answering the questionnaire.

It was important to the research group that the interview participants felt as comfortable as possible. Consequently, the time and place for the interview was decided by the participant, though we offered to conduct it at Malmö University. All participants received verbal information about the aim and content of the interview study, decided whether the interview would be recorded, and whether the research group could quote them in publications. Participants were further informed that they could withdraw their participation at any time without needing to give a reason for doing so. Lastly, each of the interview participants were provided with a folder with contact information to the student health services and victim support groups. 


\section{RESULTS}

\section{Chapter outline}

The following chapter consists of a summary of Articles 1-4. The summary includes a description of the assumptions and knowledge gaps examined in each article, along with a presentation of method $^{1}$, content and results.

\section{Article 1: Consequences of bias-motivated victimisation among Swedish university students with an immigrant or minority background}

The terminology of Article 1 differs in comparison to Articles 2-4. It was written for a special issue on contemporary racism in Europe for an Irish journal. In the absence of an established legal definition in Ireland, me and my co-author Caroline Mellgren used labels such as bias-crime and hate crime, along with racist and/or xenophobic victimization. In hindsight, this may have been more confusing than clarifying.

Firstly, I wanted to examine whether hate crime victimization resulted in behavioral changes and adaptations, a question that had been left largely unexamined at the time. Secondly, I wanted to examine the connection between experiences of hate crime and fear of crime and place-based worry. In the study, I used both survey data and interview data to answer these two questions. Lastly, I was interested in testing a field assumption, namely if the presence of a racist and/or xenophobic motive had an independent impact on fear of crime.

1 In order to make critical assessment easier, I have included method in this chapter. This makes the connections between research questions, methodological approaches and results transparent. 
At first, I wanted to integrate the results sections of the quantitative and qualitative analysis. However, when the inductive analysis of the interviews was finished I found that the content of the themes was different from the pre-determined areas of the questionnaire. These differences are summarized below along with the findings of the study.

In the survey study, we had asked if the participants had performed certain acts to avoid victimization, such as talking on the phone when walking home after dark (for the full list, see Article 1). There were no significant differences between non-victims, non-bias victims or hate crime victims on how frequent these acts were reported.

However, the interview participants did apply strategies to avoid victimization, but these were of a different kind than those measured in the survey. The strategies included acts of de-identification which centered around signaling "Swedishness". For example, participants described the importance of speaking Swedish without an accent, and forgoing clothing or items associated with their own cultural origin in order to avoid racially motivated victimization. We had no questions in our survey measuring de-identification, as such questions are not usually surveyed in studies on fear of crime.

Place-based worry was measured using descriptions of the physical characteristics of an area, and sometimes time of the day. For example, we asked how often the participants felt worry in city parks during daytime and during night-time. The victims of racially motivated hate crime generally reported higher levels of worry in comparison to nonvictims, and occasionally higher than victims of non-bias crime (for the full list, see Article 1). However, the observed differences remained small when significant.

The interview participants did not primarily assign fear or worry to the physical characteristics of a given area. Instead, they tended to feel worried in areas that they associated with bigotry and prejudice. Most drew conclusions of the attitudes in a certain area based upon their own or their friends' experiences of racist hate crime.

In the survey, fear of crime was measured as fear of specific forms of victimization (see article for detailed list of questions). Participants with experiences of racially motivated hate crime reported higher levels of fear on all questions when compared to non-victims, and on most (7 out of 9) when compared to non-bias victims. These differences were significant, 
with small to medium effect sizes. We also found that the presence of a racist and/or xenophobic motive had an independent effect on fear of crime. Women and victims of repeat victimization also reported heightened levels of fear of crime.

When fear of specific forms of victimization was discussed by the interview participants, they described experiencing fear in contexts that reminded them of previous victimization. Moreover, new acquaintances were met with suspicion until their sentiments regarding minorities had been explicitly expressed.

The discrepancies between the content of the survey and thematic analysis of the interviews illustrate that conventional measures of fear and worry does not readily capture fear and worry of hate crime. Placebased worry is not primarily associated with the physical characteristics of a certain area, and behavioral adaptations are often based upon deidentification. While fear of specific forms of victimization is described, the dimension of increased suspicion toward strangers remain absent in conventional fear of crime studies. These were results outside of the intended scope of Article 1, and which we would not have been able to observe had we relied solely on the survey study.

\section{Article 2: When there is more than one motive: a study on self-reported hate crime victimization among Swedish university students}

In Article 2, I first intended to compare consequences of hate crime between victim communities. However, two data-related problems made me reconsider. Firstly, the results of Article 1 had illustrated that some of the outcomes surveyed in the questionnaire did not correlate with the outcomes described by victims in the interviews. In other words, there was a problem regarding validity since I had reasons to doubt that some of the measures, for example on place-based worry, could be understood as a consequences of hate crime. Secondly, one in five of the survey participants with experiences of hate crime had experienced hate crimes with multiple or intersecting motives. This indicates that any categorization on the basis of motive does not result in separate groups of individuals. The latter is likely to result in false negatives through a dilution of between-group differences. 
Following a review of literature on intersectional perspectives on hate crime I decided to analyze three questions: 1 ) whether experiences of hate crime with multiple or intersecting motives influenced police reporting negatively, 2) whether belonging to several vulnerable groups correlated with higher levels of repeat victimization, and 3) whether belonging to several vulnerable groups increased likelihood of experiencing hate crime with multiple or intersecting motives. These questions corresponded to conclusions or assumptions that had remained empirically unexamined.

It is neither simple nor uncontroversial to quantify group belongings in studies on intersectionality (for a discussion, se McCall 2005). In Article 2, I based my group categories on belonging to a norm or being socially vulnerable. For example, this corresponded to being born in Sweden or being foreign-born. This classification could also be referred to as holding a social position of privilege or stigma.

I chose to create three categories based upon the number of stigmatized group belongings of the individual respondents: one group with low stigma $^{1}$, one group with medium stigma ${ }^{2}$, and one group with high stigma $^{3}$. However, quantifying these positions does not adequately capture the dynamics through which group belongings interact. For example, gender interacts differently with sexual orientation for a gay man than it does with skin color for a black man (Connell 2017). The quantitative analysis in Article 2 does not account for these nuances.

The results both rejected and confirmed assumptions made by previous researchers. The tendency to report hate crime to the police was significantly higher among victims of hate crimes with multiple or intersecting motives, rejecting the proposition made by Perry (2009) and Mason-Bish (2015). There were no significant differences in levels of repeat victimization between those with low stigma, medium stigma or high stigma. However, the probability of experiencing hate crime with multiple motives was 8 times higher among those with high stigma when compared to those with low stigma. These patterns support the branch of intersectional theory that maintains that intersecting group belongings primarily influence the expressions of violence rather than the risk of being subjected to violence.

1 Having 0-1 group belongings endowed with stigma

2 Having 2 group belongings endowed with stigma

3 Having 3-5 group belongings endowed with stigma 


\section{Article 3: How victims conceptualize their experiences of hate crime}

How victims define and create meaning from their experiences of hate crime was one of the primary questions of the EEHC and a leading cause to include interview data in the study. It has been proposed that hate crime victims hurt more because the incident targets the identity of the victim, and thereby strikes at the core of their selves (for example in Weinstein 1991 and Iganski 2001). The latter has become the leading explanation in studies with results showing that victims of hate crime hurt more in comparison to victims of non-bias crime (Herek, Gillis \& Cogan 1999, McDewitt, Balboni, Garcia \& Gu 2001, Smith, Lader, Hoare \& Lau 2012, Pezzella \& Fetzer 2017). Interview studies with victims have repeatedly showed that the victims interpret themselves as targeted due to their identity (for examples, see Chapter 2). However, I found no studies that critically assessed the proposed link between identity and self in hate crime victimization.

Following a review of a variety of qualitative methods, I found that the form of phenomenology initially proposed by Husserl (1970, 2012 originally published 1931) appeared to be the analytical approach that most readily suited my research questions. I also found the interview design of the EECH to be methodologically congruent with a model developed for conducting interviews for phenomenological analysis (Englander 2012).

The analytical approach in Husserl's $(1970,2012)$ phenomenology differed greatly from the thematic content analysis that I had conducted for Article 1. Content analysis is a way of separating data, for example interviews, into categories of difference, while Husserl's (1970, 2012) phenomenology is an analysis of connections and pathways. Consequently, the structure of the results for Article 3 could be described as interactive clusters connected by nodal pathways. The latter became a challenge for presenting the results in an accessible text format. I chose a structure of presentation in which I began by presenting key clusters, such as identity, and added the nodal pathways as new clusters were presented, such as the connections between identity, markers and prejudice.

The analysis identified a terminological gap between researchers, politicians and interest organizations on the one hand, and victims on the 
other. The participants rarely used the term hate crime to describe their experiences. Instead, they used the system of oppression, such as islamophobia or racism, as signifiers when describing their experiences.

Hate crime was understood as prejudice-based actions targeting one or more group identities of the victim via visible identity markers. Prejudice was described as connected to a social hierarchy with an idealized norm at the top. Consequently, the explanatory frameworks of the participants were largely in line with those proposed by researchers, politicians and interest organizations.

Having markers endowed with stigma resulted in the need to navigate contradicting narratives. Stigma was primarily encountered in popular culture, and during interaction with members of out-groups or institutions. However, the stigma was often absent on an in-group basis. For example, homosexual participants described how their relationships were perceived as expressions of love by other members of their community, and not as sick or perverse as in the negative stereotype. Consequently, the object targeted during a hate crime incident is not the self of the victim as proposed by Iganski (2001), but a negative stereotype. The act however, remains a violation of the self as it denies the victim their possibility of self-representation.

There were also other factors associated with how personal a hate crime incident felt for the participants, such as the accuracy of the offender's classification of their identity and the strength of the relationship between the victim and the group community the prejudice was directed against.

The meaning-making regarding experiences of hate crime can be described as reflexive - the participants used earlier experiences of similarity and previous story arcs when assigning meaning to incidents. This process was also recursive as new incidents lead to re-interpretations of previous experiences; the participants developed and negotiated their experiences of hate crime over time.

Most of the participants also used parallel frameworks for understanding experiences of hate crime. These parallel frameworks do not always account for the structural dynamics of the incidents. For example, one participant described being harassed by a group of young men. She referred to this incident as "racially motivated" at one point during the interview, and as "young men just acting out" at another. 
Therefore, hate crime could be metaphorically likened to a house with several, rather than just one, points of entrance.

\section{Article 4: Does having friends with experiences of hate crime increase fear of crime among women, sexual minorities and Muslims?}

After taking a different approach in Article 2 than originally planned, I wanted to re-examine the possibility to make some form of analysis on community-based consequences of hate crime victimization. Judging from the results of previous research (see Chapter 2), it is reasonable to assume that manifestations of de-identification should be group-related. However, the material I worked with had no measures of deidentification as most of the studies presented in Chapter 2 had not been published when the study was designed.

There was however one measurement in the study that I and my coauthors had identified as a consequence of hate crime victimization in Article 1: fear of crime. Moreover, it has been proposed that fear of crime spreads through victim communities, and that vicarious victims respond in ways similar or equal to initial victims (Weinstein 1991, Iganski 2001, Perry 2001, Lawrence 2006). This phenomenon, by some referred to as the in terrorem effect, has been observed and described in greater detail in empirical research (Noelle 2002, Perry \& Alvi 2011, Bell \& Perry 2015). However, most studies about community effects were based on small samples. To my knowledge, the first study presenting data about community effects of hate crime on aggregated level was published in 2018 (Paterson, Walters, Brown \& Fearn 2018), after the first revisions of the drafts for Article 4 had been conducted.

Despite there being few empirical studies on the subject, there were clear theoretical propositions made on how the in terrorem effect should express itself. Firstly, previous researchers maintained that vicarious victims should be more afraid in comparison to individuals without friends with experiences of hate crime (here-after referred to as nonvictims). Secondly, vicarious victims should respond to hate crime in similar ways as direct victims. The combination of these two propositions also result in a third one, namely that direct victims should be more afraid in comparison to non-victims. These three theoretical propositions were used as hypotheses in Article 4. 
Three victim communities were selected for the study: women, Muslims, and sexual minorities. These are communities organized over different kinds of identity markers. Women are primarily grouped together by bodily appearance, Muslims by confession of faith, and sexual minorities by preferences regarding intimate relationships. The members of these communities were divided into three groups: nonvictims, vicarious victims, and direct victims. The same group divisions were used in Paterson, Walters, Brown and Fearn (2018).

In the first statistical models I ran, I isolated the misogynistic hate crime for women, anti-religious hate crime for Muslims, and homophobic hate crime for sexual minorities. I also isolated vicarious victims within each group who had friends with experiences of hate crime targeting their sex/gender, religion or sexual orientation respectively. However, after revisiting the theoretical propositions, I decided to test Iganski's (2001) proposition that hate crime can have an in terrorem effect regardless of motive. I also reasoned that such an approach would better account for the diversity of the studied communities. This second wave of models showed larger effect sizes, and had a better model fit wherefore these were selected for the results in the final article.

The results showed that the largest differences between vicarious victims and non-victims in fear of crime were present in the community of women. Direct victims were generally more afraid of crime in comparison to non-victims in all communities. Similar reactions between vicarious victims and direct victims were primarily observed among Muslims and sexual minorities.

Though not all differences were significant, the reaction pattern among non-victims, vicarious victims and direct victims in the studies communities showed the pattern of a stair, with the lowest rates of fear among non-victims and the highest rates among direct victims. This pattern is also observed by Paterson, Walters, Brown and Fearn (2018). Article 4 therefore shows that some of the present assumptions regarding the community impacts of hate crime need to be adjusted, at least regarding fear of crime.

Moreover, the article identifies methodological inconsistencies in measurement of community effects. Some measure effects of media reporting, some of having friends with experiences of victimization, and some combine these approaches. Furthermore, some studies are 
experimental in design and measure acute consequences among participants when confronted with a stressor; others measure persistent consequences in the everyday lives of the participants. Consequently, the results remain difficult to contextualize as they are often derived from studies of different forms of community effects. 


\section{DISCUSSION}

\section{Chapter outline}

In the following discussion, focus is directed to field implications, theoretical implications, and policy implications. Suggestions regarding directions for future research are integrated into each part.

The implications of the present dissertation need to be interpreted with care. Firstly, the implications are drawn from the interpretational capacity of victims rather than offenders. This is of relevance when conclusions about offenders are drawn. Secondly, the participants in the present study are students. Hence, the symbolic universe of the participants is influenced by theories present within academia.

\section{Field implications}

In Article 1, we find support for the claim that hate crimes hurt more by comparing fear of crime between victims of racially motivated hate crime and victims of non-bias crime. However, the regression analysis also shows that a large part of the difference between hate crime victims and victims of non-bias crime remain unaccounted for in the model. Consequently, there is a need for further understanding of factors that influence the levels of fear of crime among hate crime victims. The same holds true for other emotional outcomes, such as anxiety, depression, anger, shame, and the like. Potential moderators of emotional outcomes are tendencies towards self-objectification, isolation, dissociation, and strength of integrity (Herman 2015); relationship to the offender (Herman 2015, Article 3); the strength of the identification with the group identity targeted during the incident (Paterson, Walters, Brown and Fearn 2018, Article 3); perceived benevolence of the world (Janoff- 
Bulman 1989); accuracy of the offenders classification of the victim (Article 3); and the presence of stigma (Lawrence 2006, Goffman 2011).

The themes and patterns of consequences of hate crime described by the participants in Article 1 holds true for the interviewed victims across motives. Instead, the variations are connected to the de-identification process directed toward different identity markers.

The results of Article 1 also show that markers of race, ethnicity or nationality vary greatly in visibility. Articles 1-3 illustrate how the visibility of identity markers has a profound effect on the experiences of victimization and the experience of "being in the world". Those with highly visible markers endowed with stigma experience overt forms of othering, while those with less visible markers find themselves in contexts where they are covertly othered. Overt othering is, for example, direct anti-Semitic slurs targeting someone perceived to be Jewish. Covert othering is, for example, when someone expresses anti-Semitism in a group of people of which one or more have a non-visible Jewish group belonging. The overtly othered will find themselves in a situation in which they are expected to participate in the othering of themselves.

The results from the EEHC shows that covert othering has a negative impact on victims (in line with Goffman 2011) as these individuals are torn between their desire of social inclusion on the one hand, and the realization that inclusion comes at the price of staying closeted. The social inclusion in such cases is an illusion, as the covertly othered individual knows that they are not allowed to participate in the social group in their capacity as full human beings.

The results of Article 2 reject the assumption that hate crime with multiple or intersecting motives results in a lowered tendency to report the incident to the police. The results of Article 2 also show that factors that influence police reporting for other forms of crime, such as crime type, also influence the tendency to report hate crime. Moreover, in an article published in a Swedish peer-reviewed journal, me and Caroline Mellgren further assessed the tendency to report hate crime to the police (Andersson \& Mellgren 2015). The results of the study identified factors that influenced police reporting negatively. Firstly, many victims tended to trivialize their experiences, arguing that derogatory comments, harassment and threats were not incidents "serious enough" for police reporting. Secondly, many victims normalized experiences of hate crime 
because bystanders remained passive, and because many had been repeat victims of hate crime. These two factors signaled that hate crime incidents were "okay" and to be expected. Thirdly, some victims found alternative paths of dealing with the offender in a satisfactory way outside of the justice system. For example, one participant was verbally assaulted by a bus-driver due to the driver's prejudice against people with her skin color. Instead of reporting the incident to the police, she reported it to the bus company. Lastly, some refrained from reporting hate crime because they had a low trust in the police. These participants often referred to news articles that revealed bigoted attitudes within the police authority (Andersson, Mellgren 2015). It is of interest to examine the aggregated impact of these factors quantitatively in future studies on hate crime and police reporting.

Furthermore, Article 2 clearly illustrates the need for development of methodological approaches for examining intersectionality quantitatively. The label "multiple motives" is used more extensively in the article than the label "intersecting motives". The latter is primarily related to being transparent with how identity categories were operationalized in the analysis. However, it is also evident that some markers coalesce into unique forms of stigma, such as gender and race, gender and sexual orientation, and religion and race. In larger sample sizes, these should preferably be operationalized as interaction terms. Other group belongings appear culturally separated in a Swedish context, like sexual orientation and religion, or sexual orientation and race. These combinations could instead be operationalized using the method for categorization described in Article 2.

In Article 3 we find some support for the assumption that hate crime hurts more because it targets the self of the victim. Hate crime targets a negative stereotype and thereby denies the victim self-representation. In this sense, it is not entirely semantically correct to say that hate crime targets the victim's self, as it is more correct to say that it violates the victim's self. The following factors further influenced how personal a hate crime incident felt: the correctness of the classification of the offender, the identification with the community represented by the targeted identity marker, the interchangeability of the victim and the behavior of the offender during the incident. 
That victims rarely use the label hate crime for their experiences has methodological implications. In EEHC, interview participants were recruited through a survey asking about experiences of crime motivated by prejudice. Some of the interview participants explained how answering the questionnaire added a new dimension to their experiences. They had perceived them as motivated by prejudice but not as hate crime, and many remained hesitant to apply the label hate crime to their experiences. However, it seems as if though it is common among hate crime researchers to use the label hate crime when approaching study participants. Such procedure may therefore unintentionally exclude individuals with experiences of hate crime due to their reluctance to address their experiences using that label.

The experiences of victims are in a constant state of re-interpretation and negotiation as new experiences are integrated into their interpretational framework. The fact that victims tend to find different entrance points and theoretical frameworks for understanding their experiences shows that these experiences are less static than they are often presented. Further examination into what victims achieve by approaching experiences from different perspectives is of interest, and so is an examination of which alternative frameworks are most commonly used.

In Article 4, we find that the fear of crime does not spread within the communities of women, Muslims, and sexual minorities in a pattern consistent with propositions made by previous authors. The results also show that the differences between non-victims and vicarious victims were largest in the community of women.

The levels in fear of crime appear to be related to the kinds of victimization that individuals within the communities are subjected to. Experience of verbal harassment is the most common form of hate crime in the EECH cross communities, and it was also this crime type that most participants in the studied communities reported being fearful of.

Moreover, Article 4 illustrates the variety in methodological approaches taken by scientists when studying community effects of hate crime. In short, there appears to be a lack of coherency between how communities and community effects are defined and operationalized, making results different to compare and contextualize. 
It is my belief that there is a need for an in-field discussion about the differences in acute and persistent consequences of hate crime. I use the term acute consequences to describe the direct emotional and behavioral response following a hate-related stressor, such as reading about a hate crime in the news, listening to friends talking about experiences of victimization, and experiencing direct victimization. Acute consequences should not be interpreted as temporally brief, as the process of cognitive reorganization after encountering a stressor may take months. I use the term persistent consequences to describe the remnants following such a cognitive reorganization. These can remain part of the individual's everyday life over the course of many years, sometimes permanently.

As presented above, the results of the present dissertation call for a more complex understanding of both individual and community effects of hate crime. It has become clear to me that when I began working on my dissertation, I had an overly simplified understanding of what "consequences of hate crime" was. Despite having conducted literature reviews on studies of consequences of hate crime victimization, I was not fully prepared for all the variations I would encounter. In Table 6, I summarize four different categories of consequences that I have encountered during my time working with the EEHC and while reading studies on consequences of hate crime. The table accounts for the difference between acute and persistent consequences as discussed in Article 4. Moreover, community-specific consequences are separated from generic consequences.

Table 6: Four categories of consequences of hate crime among individuals and communities

\begin{tabular}{|lll|}
\hline & $\begin{array}{l}\text { Acute } \\
\text { consequences }\end{array}$ & $\begin{array}{l}\text { Persistent } \\
\text { consequences }\end{array}$ \\
\hline Generic consequences & $\begin{array}{l}\text { When exposed to a } \\
\text { stressor, } \\
\text { observable across } \\
\text { communities }\end{array}$ & $\begin{array}{l}\text { Continuous and } \\
\text { observable across } \\
\text { communities }\end{array}$ \\
\hline $\begin{array}{l}\text { Contextual } \\
\text { consequences }\end{array}$ & $\begin{array}{ll}\text { When exposed to a } \\
\text { stressor, } \\
\text { community specific }\end{array}$ & $\begin{array}{l}\text { Continuous and } \\
\text { community specific }\end{array}$ \\
\hline
\end{tabular}


Table 6 can be a heuristic tool for assessing the comparability of results between studies using different methodological approaches to assess individual and community effects of hate crime.

\section{Theoretical implications}

\section{Hate crime causation}

The results of the EEHC confirm the presence of behavioral asymmetry as presented by Sidanius \& Pratto (1999). In the survey study, this proposition is supported by the large and significant difference in likelihood to be subjected to hate crime between different groups, especially when taking visibility into account (for overviews, see Andersson \& Mellgren 2015, 2016). In the interview study, this proposition is supported by how victims with occasionally visible markers describe being treated differently when markers are visible and when they are not.

The verbal interaction between victims and offenders supports the proposition that offenders believe that there are inherent differences between individuals based on group belongings (as proposed by Blumer 1958, Sidanius \& Pratto 1999, and Connell 2017). These aspects also support the notion of hate crime as part of an enactment of collective rather than individual identities (Perry 2001, Goffman 2011, Connell 2017). However, the results do not inform us whether offenders have a poorly developed self, or if the male offenders are individuals who fail at performing hegemonic masculinity in their everyday lives (Chakraborti \& Garland 2012, Connell 2017).

There is a theoretical conflict between Goffman (2011) and Sidanius \& Pratto (1999) regarding the enforcement of hierarchies. Goffman (2011) holds that hierarchy enforcement is a top-down practice, while Sidanius \& Pratto (1999) hold that hierarchies can be enforced by anyone who endorses the belief in inherent differences between groups. The results of the EEHC are in support of Sidanius and Pratto (2011), showing that offenders can belong to an out-group higher up in a social hierarchy than the victim, an out-group further down in a social hierarchy than the victim, or be an in-group member who polices the behavioral repertoire of other in-group members.

The incidents described by victims in the interviews and open-ended survey questions also indicate that they are mostly the results of perceived 
provocations (as proposed by Blumer 1958, Perry 2001 McDewitt, Levin \& Bennet 2002, Chakraborti \& Garland 2012). The incidents also appear to be moderated by situational factors, as the incidents described by victims are often characterized by a situational absence of capable guardians (as proposed by Chakraborti \& Garland 2012).

There are, however, no incidents that can be classified as instigated by a lack of self-control as proposed by Chakraborti and Garland (2012). Instead, the offenders appear to act on their prejudiced beliefs in some situations, while refraining from acting on the same beliefs in other situations. Moreover, very few of the described incidents can be classified as performed by what McDewitt, Levin and Bennet (2002) referred to as retaliatory offenders or mission offenders.

The results of the present dissertation support the stratums developed in the stratified ontology in Chapter 3. The presence of group identities ordered in a social hierarchy based upon perceived group characteristics are described by the interview participants in Article 1 and Article 3. Moreover, the participants in the interview study describe how doing difference on the basis of gender, race, religion, disability and sexual orientation is part of their everyday lives. Lastly, hate crime was perceived as a form of doing difference, albeit more violent and/or threatening.

The stratified ontology also allows for the development of several hypotheses that lead up to Popper's (2002, first edition published in 1963) criteria of falsification. These hypotheses cannot be examined by the data collected in the EEHC but should be read as suggestions for future research.

To begin with, hate crime directed downwards in a social hierarchy should be committed by individuals who endorse hierarchy-enhancing myths and have a poorly developed sense of self. Men who engage in hate crime should be men who, despite their aspiration, have failed to adhere to what Connell (2017) refers to as hegemonic masculinity. Hate crime instigated by thrill-seeking offenders should be performed by offenders who have ritualized practices of violence and intimidation to compensate for their poorly developed selves and inability to adhere to hegemonic masculinity.

Little guidance is provided in the theories integrated in the model regarding the specific driving forces of female offenders. It stands to 
reason, however, that female offenders who engage in hate crime directed downwards in a social hierarchy should also endorse hierarchy-enhancing myths and have a poorly developed sense of self.

Moreover, all individuals who commit hate crime directed downwards in a social hierarchy should have a strong sense of entitlement to the servitude from those targeted.

Hate crime occurring between or within stigmatized groups should be committed by individuals who endorse hierarchy-enhancing myths. These offenders should be highly invested in the hierarchical order, for example by being a person who have attained the highest possible status within the group.

All hierarchy-enhancing hate crimes should target perceived threats to the hierarchical structure enforced by the crime. Further, there should be situational factors that govern decision-making when a perceived threat occurs. The perceived likelihood of a successful re-establishment of the hierarchical order should be central.

Lastly, retaliatory hate crime should be committed by individuals who endorse hierarchy-attenuating myths.

\section{Consequences of hate crime}

The three forms of stigma (physical appearance, individual character, and tribal constructs) presented by Goffman (2011) are present in the experiences of the interview participants. It should be noted, though, that only three of the interview participants had experiences of being targeted due to their disability, and so the conclusions regarding this form of stigma are based upon very few participants. In general, sexual minorities and participants with psychological disabilities described stigma as connected to personal character, while religious minorities and people of color described stigma as connected to tribal constructs.

Moreover, Herman's (2015) theories of trauma further inform the results of Articles 1,3 and 4. The results show that hate crime and othering in general impair the possibility for stigmatized groups to be socially included.

Participants who were subjected to othering and hate crime by their peers in schools described how their experiences negatively impaired their possibility to form a sense of local community and belonging. For many, it became important to form safe spaces and contexts in which they were 
able to be themselves without having to deal with the negative stereotype associated with their identity markers.

Participants who were subjected to othering and hate crime by strangers and institutions described how it negatively impaired their possibility to form a connection to society, and was coupled with feelings of alienation and injustice.

The most severe consequences were described by those subjected to othering and hate crime by family members. These participants experienced identity crisis and engaged in destructive behaviors, including alcohol and/or drug abuse, self-harm, and destructive sexual behaviors. The behaviors described by those accepted but not endorsed by their families were similar but less extreme. According to Herman (2015), the crises of identity and integrity in these cases are the direct consequences of a collapsed sense of self, stemming from the objectification and the breakdown of the bridge of trust between the individual and their social context.

The interview participants formed expectations of the future based upon previous experiences. However, in contrast to Assumptive World Theory (Janoff-Bulman 1989), these expectations were not characterized by the belief of living in a benevolent world. Instead, they were characterized by the belief of living in a world in which the outlooks of people vary greatly, largely due to a hierarchical system based on arbitrarily constructed group categories. Nor did the interview participants resort to victim blaming as a way of defending the idea of a benevolent world, as observed by Noelle (2002). Indeed, the participants were highly aware of which behaviors and aesthetic expressions resulted in a heightened risk of being subjected to hate crime. Many also had mental maps of which areas were safe and unsafe to spend time in. However, the participants regarded the presence of these risk factors as inherently unfair and did not blame people who were victimized because they had transgressed these borders. The latter may be a result of the different cultural contexts in which the EEHC and the study by Noelle (2002) were conducted, as well as the timespan between them.

Based on the results of the EEHC and theory on consequences of hate crime presented in Chapters 2 and 5, I have compiled a list of hypotheses of interest for future research. 
Firstly, victims who are targeted because they belong to a stigmatized group should report more harm in comparison to victims who are targeted because they belong to a non-stigmatized group (Perry 2001, Iganski 2001, Lawrence 2006, Goffman 2011). Similarly, victims with a strong group identity should report more harm in comparison to victims with a weak group identity (Paterson, Walters, Brown \& Fearn 2018, Article 3), and victims who are correctly categorized by offenders should report more harm in comparison to victims who are incorrectly categorized (Article 3).

Furthermore, victims who belong to stigmatized groups and endorse hierarchy-enhancing myths should report higher levels of self-contempt in comparison to those who reject hierarchy-enhancing myths (JanoffBulman 1989, Sidanius \& Pratto 1999, Noelle 2002). On the other hand, victims belonging to stigmatized groups who reject hierarchy-enhancing myths should report higher levels of fear and anxiety in comparison to victims who endorse the idea of a benevolent world (ibid.).

Finally, I propose that victims who have been targeted by members of their family should report more harm in comparison to those targeted by peer groups and strangers (Herman 2015). Victims who have been targeted by members of their peer group should report more harm in comparison to those targeted by strangers. Victims targeted by members from their primary group should report feelings of individual isolation, and victims targeted by peer groups and strangers should report feelings of isolation from society (ibid.).

\section{Policy implications}

The results of the present dissertation and other studies on hate crime victimization in a Swedish context challenge the notion of hate crime as a form of crime that primarily targets the democratic regime of governance. Hate crime might have a detrimental effect on the state of the Swedish democracy, but focusing solely on outcomes at such a high level of abstraction hardly accounts for the full impact of hate crime. The results of the present dissertation show that this is a form of crime that first and foremost harms the direct victims.

Moreover, I find no support for the understanding of homo-, bi-, and transphobic hate crime as internal to racism, a view presented in SOU 2000:88, and by Regeringskansliet (2016). Instead, scientific theory and 
the results of the present dissertation alike suggests that hate crimes targeting sexual and racial minorities originate in separate hierarchical systems of oppression.

Lastly, the results of the present dissertation challenge the recent dismissal of a proposal suggesting the inclusion of gender identity and gender expression as categories for protection under hate crime legislation. The results of the present dissertation identify misogynistically motivated hate crime targeting women as the numerically largest category of victims.

In sum, the results call for 1) a widened discussion in official reports and documents regarding the consequences of hate crime in which the harm done to direct victims are taken into account, 2) a development of the theoretical understanding of hate crime targeting sexual minorities in Swedish politics, and 3) the inclusion of gender identity and gender expression in present legislation. 


\section{POPULÄRVETENSKAPLIG SAMMANFATTNING}

Hatbrott är ett samlingsbegrepp för de brott som motiveras av gärningspersonens fientlighet gentemot brottsoffrets uppfattade grupptillhörighet. Det kan exempelvis röra sig om fientlighet gentemot brottsoffrets uppfattade religion, sexuella läggning, funktionsnedsättning, könsidentitet, nationalitet eller etnicitet.

Hatbrottsstudier är ett ungt fält och i Sverige slog begreppet hatbrott igenom först under tidigt 00-tal. Forskning om hatbrott består i stor utsträckning av utforskande studier med öppna och breda frågeställningar. Genom ett sådant tillvägagångssätt tar forskaren hänsyn till de kunskapsbegräsningar som karaktäriserar unga fält. Dessutom resulterar sådana studier ofta $\mathrm{i}$ en direkt kunskapsutveckling $\mathrm{i}$ form av teoretiska slutsatser och antaganden utifrån resultaten. I den här avhandlingen undersöker jag och mina medförfattare fyra sådana antaganden närmare $\mathrm{i}$ en kombinerad enkät- och intervjustudie bland studenterna på Malmö universitet.

I den första artikeln undersöker vi antagandet att hatbrott får svårare konsekvenser för offren i jämförelse med brott utan sådant motiv. Vi testar antagandet genom att jämföra rädsla för brott, strategier för att undvika utsatthet för brott och oro bland de studenter som har utländsk bakgrund eller tillhör en nationell minoritet. Resultaten visade att de som utsatts för hatbrott är mer rädda för brott $\mathrm{i}$ jämförelse med offer för brott med andra motiv, såväl som de som inte utsatts för några brott. Det fanns däremot få skillnader i strategier för att undvika utsatthet för brott och upplevd oro på olika platser. Utifrån intervjuerna med studenter som varit utsatta för rasistiskt motiverade hatbrott kunde vi dra slutsatsen att 
oro inte var kopplat till typer av platser, såsom ett krogområde. Oron var istället kopplad till geografiska koncentrationer av rasistiska attityder. Detta innebar exempelvis att ett av Malmös vanliga krogområden upplevdes som tryggt, samtidigt som ett annat krogområde upplevdes som otryggt. Därutöver berättade intervjudeltagarna att de strategier som användes för att undvika brott ofta var kopplade till att försöka signalera svenskhet, exempelvis genom att tala utan brytning eller genom klädstil. Dessa var av en annan sort än de strategier vi undersökt i enkätstudien, som exempelvis bestod $i$ att prata $i$ telefon om man promenerar hem efter mörkrets inbrott. Sammanfattningsvis kan man säga att de mått som forskare vanligtvis använder för att studera platsbaserad oro och strategier för att undvika utsatthet för brott inte fångar upp oro eller strategier för att undvika hatbrott.

I den andra artikeln undersöker vi antagandet att anmälningsbenägenheten är lägre bland de som utsatts för hatbrott med flera motiv. Det kan exempelvis röra sig om hatbrott som motiveras av en fientlighet gentemot offrets hudfärg och religion på en och samma gång. I motsats till detta antagande visade resultaten att anmälningsbenägenheten var högre bland de som hade utsatts för hatbrott med överlappande motiv än bland de som hade utsatts för hatbrott med enskilt motiv. Vidare visade resultaten att utsatthet för hatbrott med överlappande motiv var vanligare bland studiedeltagare med flera normbrytande identitetskategorier. Att ha flera normbrytande identitetskategorier kunde exempelvis vara att samtidigt tillhöra en sexuell minoritet, vara kvinna och ha en funktionsnedsättning. Det var däremot inte vanligare att deltagarna med flera normbrytande identitetskategorier utsattes för hatbrott upprepade gånger. Resultaten visar därmed att identitetskategorier formar de uttryck som hatbrotten tar, men inte påverkar risken att utsättas upprepade gånger.

I den tredje artikeln undersöker vi antagandet att hatbrott upplevs som ett angrepp på offrets identitet och därmed även offrets jag. Resultaten av studien visade istället att hatbrotten riktas mot en negativ stereotyp som offret inte identifierar sig med. Därför upplevdes hatbrotten inte som direkta angrepp på offrets jag. Hatbrotten gjorde dock våld på offrets jag eftersom den utsatte blir påtvingad en negativ stereotyp och förnekas möjligheten till att representera sig själv. Vidare visade resultaten att offren i stor utsträckning använder tidigare erfarenheter för att skapa 
mening kring sin utsatthet för hatbrott. Nya erfarenheter kunde också förändra innebörden i tidigare erfarenheter. Detta innebär att offren ändrar och omförhandlar sitt förhållningssätt till sina erfarenheter av hatbrott över tid.

I avhandlingens fjärde och sista artikel undersöker vi antagandet att hatbrott får spridningseffekter i form av ökad rädsla, eftersom hatbrott signalerar intolerans och hot om våld bortom det direkta offret. På grund av denna spridningseffekt har tidigare forskare dragit slutsatsen att indirekta offer, alltså de som har vänner som utsatts för hatbrott, reagerar som direkta offer. Resultaten visade att direkta offer var mer rädda för brott i jämförelse såväl indirekta offer som deltagare som inte hade direkta eller indirekta erfarenheter av hatbrott. Dessa skillnader var förvisso inte alltid anmärkningsvärda, men visar att spridningseffekten av hatbrott kan liknas vid en trappa, med högst rädsla bland direkta offer och lägst rädsla bland deltagare utan direkta eller indirekta erfarenheter av hatbrott. Det fanns således begränsat stöd för antagandet att indirekta och direkta offer för hatbrott skulle reagera likadant.

Sammantaget visar resultaten att det behövs en mer nyanserad bild av hatbrottens orsaker och konsekvenser. Det vore till exempel konstruktivt att undersöka huruvida negativa konsekvenser av hatbrott påverkas av hur starkt en individ identifierar sig med den identitet som angrips, och vilken relation offret har till gärningspersonen. Vidare är det av intresse att undersöka huruvida gärningspersoner omfamnar föreställningen om att människor har olika värde beroende på vilken grupp de tillhör. 


\section{ACKNOWLEDGEMENTS}

The EECH was co-funded by the Swedish Crime Victim Compensation and Support Agency.

I would like to thank my colleagues at the Department of Criminology at Malmö University. In particular, I would like to thank my fellow $\mathrm{PhD}$ students and my supervisors. You have contributed to my personal growth and development by offering guidance, sharing ideas and making me see new perspectives. Thank you.

I would also like to thank my friends and self-selected family for their endless encouragement, patience, love and friendship. Thank you. 


\section{REFERENCES}

Ahlin, A. and Gäredal, M. (2009) Effekter av heteronormen. En studie om utsatthet för sexuella övergrepp, sexuell gränssättning samt utsatthet för hatbrott bland unga hbt-personer. RFSL Ungdom.

Andersson, M. (2016) Theoretical challenges in contemporary hate crime studies. Scandinavian Research Council for Criminology, Annual report.

Andersson, M. and Mellgren, C. (2015) Anmälningsbenägenhet vid utsatthet för hatbrott. Socialvetenskaplig Tidsskrift, 3(4), pp. 283-301.

Andersson, M. and Mellgren, C. (2016) Studenters utsatthet och upplevelser av hatbrott. Malmö högskola, FoU rapport 2016:1.

Bell, J. and Perry, B. (2015) Outside looking in: the community impacts of antilesbian, gay and bisexual hate crime. Journal of Homosexuality, 62, pp. 98-120.

Bhaskar, R. (2005) The possibility of naturalism: a philosophical critique of the contemporary human sciences. $3^{\text {rd }}$ ed. London: Routledge.

Blumer, H. (1958) Prejudice as a sense of group position. The Pacific Sociological Review, 1(1), pp. 3-7.

BRÅ (2006) Hatbrott 2005: En sammanställning av polisanmälningar med främlingsfientliga, antisemitiska, homofobiska och vit-makt ideologiska motiv. Brottsförebyggande Rådet, Rapport 2006:3.

BRÅ (2009) Hatbrott 2008: Polisanmälningar där det i motivbilden ingår etnisk bakgrund, religiös tro, sexuell läggning eller könsöverskridande identitet eller uttryck. Brottsförebyggande Rådet, Rapport 2009:10.

BRÅ (2013) Hatbrott 2012: Statistik över självrapporterad utsatthet för hatbrott och polisanmälningar med identifierade hatbrottsmotiv. Brottsförebyggande Rådet, Rapport 2013:16.

BRÅ (2017) Hatbrott 2016: Statistik över polisanmälningar med identifierade hatbrottsmotiv och självrapporterad utsatthet för hatbrott. Brottsförebyggande Rådet, Rapport 2017:11. 
Bunar, N. (2007) Hate crimes against immigrants in Sweden and community responses. American Behavioral Scientist, 51(2), pp. 166-181.

Chahal, K. (2017) Supporting victims of hate crime: a practitioner guide. Bristol: Policy Press.

Chakraborti, N. and Garland, J. (2012) Reconceptualizing hate crime victimization through the lens of vulnerability and difference. Theoretical Criminology, 16(4), pp. 499-514.

Chakraborti, N. (2015) Framing the boundaries of hate crime. In: Hall, N. Corb, A. Giannasi, P. Grieve, J. eds. (2015) The Routledge international handbook on hate crime. London: Routledge.

Chakraborti, N. and Garland, J. eds. (2015) Responding to hate crime: the case for connecting policy and research. Bristol: Policy Press.

Connell, R W. (2017) Masculinities. $2^{\text {nd }}$ ed. Cambridge: Policy Press.

Crenshaw, K. (1991) Mapping the margins: intersectionality, identity politics, and violence against women of color. Stanford Law Review, 43(6), pp. 1241-1299.

Englander, M. (2012) The interview: data collection in descriptive phenomenological human scientific research. Journal of Phenomenological Psychology, 43(1), pp. 1335.

Gardell, M. (2017) What's love got to do with it?: ultranationalism, Islamophobia and hate crime in Sweden. Journal of Religion and Violence, 3(1), pp. 91-115.

Goffman, E. (2011) Stigma: det avvikandes roll och identitet. $4^{\text {th }}$ ed. Lund: Studentlitteratur.

Granström, G. (2016) Kan offer för könsrelaterat våld ses som offer för hatbrott? In: Granström, G. and Mannelqvist, R. (2016) Brottsoffer: rättsliga perspektiv. Lund: Studentlitteratur.

Hall, N. (2015) Understanding hate crimes: sociological and criminological perspectives. In: Hall, N. Corb, A. Giannasi, P. Grieve, J. eds. (2015) The Routledge international handbook on hate crime. London: Routledge.

Hall, N. Corb, A. Giannasi, P. and Grieve, J. eds. (2015) The Routledge international handbook on hate crime. London: Routledge.

Herek, G M. Gillis, J R. and Cogan, J C. (1999). Psychological sequelae of hate-crime victimization among lesbian, gay, and bisexual adults. Journal of Consulting and Clinical Psychology, 67(6), pp. 945-951.

Herman, J L. (2015) Trauma and recovery: from domestic abuse to political terror. London: Pandora.

Husserl, E. (1970) The crises of European sciences and transcendental phenomenology, an introduction to phenomenological philosophy. Evanston: Northwestern University Press.

Husserl, E. (2012) Ideas I-III. London: Routledge. 
Iganski (2001) Hate crime hurts more. American Behavioral Scientist, 45(4), pp. 626638.

Iganski (2008) 'Hate crime' and the city. Bristol: Policy Press.

${ }^{a}$ Iganski, L. and Levin, J. (2015) Hate crime: a global perspective. New York: Routledge.

'Iganski, L. and Levin, J. (2015) Hate crimes hurt some more than others: implications for the just sentencing of offenders. Journal of Interpersonal Violence, 30(10), pp. 1696-1718.

Isaksson, R. (2018) Lagstifta om hatbrott mot personer med funktionsnedsättning. Delaktighet Handlingskraft Rörelsefrihet. Availbable at https://dhr.se/lagstifta-omhatbrott-mot-personer-med-funktionsnedsattning/. Accessed $16^{\text {th }}$ of April 2018.

Janoff-Bulman, R. (1989) Assumptive worlds and the stress of traumatic events: applications of schema construct. Social Cognition, 7(2), pp. 113-136.

Jeaness, V. and Grattet, R. (2001) Making a hate crime: from social movement to law enforcement. New York: The Russel Sage Foundation.

Kalonaityté, V. Kawesa, V. and Tedros, A. (2007) Att färgas av Sverige: upplevelser av diskriminering och rasism bland ungdomar med afrikansk bakgrund i Sverige. Ombudsmannen mot etnisk diskriminering.

Lagrådet (2017) Ett utvidgat straffrättsligt skydd för transpersoner. Protokoll 201709-25.

Lawrence, F M. (2006) The hate crime project and its limitations: evaluating the societal gains and risk in bias crime law enforcement. Public law and legal theory, working paper no. 216.

Mason-Bish, H. (2015) Beyond the silo: rethinking hate crime and intersectionality. In: Hall, N. Corb, A. Giannasi, P. Grieve, J. eds. (2015) The Routledge international handbook on hate crime. London: Routledge.

McCall, L. (2005) The complexity of intersectionality. Signs, 30(3), pp. 1771-1800.

McDewitt, J. Balboni, J. Garcia, L. and Gu, J. (2001) Consequences for victims: a comparison of bias- and non-bias-motivated assaults. American Behavioral Scientist, 45(3), pp. 697-713.

McDewitt, J. Levin, B. and Bennet, S. (2002) Hate crime offenders: an expanded typology. Journal of Social issues, 58(2), pp. 303-317.

Mellgren, C. Brax, D. and Bladini, M. (2017) Mäns våld mot kvinnor bör ses som hatbrott. Svenska Dagbladet. Available at https://www.svd.se/mans-vald-motkvinnor-bor-ses-som-hatbrott. Accessed $16^{\text {th }}$ of April 2017.

Michaels, L. (2015) Hate crime against students: recent development in research, policy and practice. In: Chakraborti, N. Garland, J. (eds.) (2015) Responding to hate crime: the case for connecting policy and research. Bristol: Policy Press. 
Moffitt, T E. Caspi, A. Rutter, M. and Silva, P A. (2006) Sex differences in antisocial behavior. Cambridge: Cambridge University Press.

Moraga, C. and Anzaldúa, G. (2015) This bridge called my back: writings of radical women of color. $4^{\text {th }}$ ed. New York: State University of New York Press.

Noelle, M. (2002) The ripple effect of the Matthew Shepard murder. American Behavioral Scientist. 46(1), pp. 27-50.

Otterbeck, J. and Bevelander, P. (2006) Islamofobi - en studie av begreppet, ungdomars attityder och unga muslimers utsatthet. Forum för Levande Historia.

Paterson, J. Walters, M A. Brown, R. and Fearn, H. (2018) The Sussex hate crime project. University of Sussex, final report.

Perry, B. (2001) In the name of hate. New York: Routledge.

Perry, B. (2012) Identity and hate crime on Canadian campuses. Race and Justice, 1(4), pp. 321-340.

Perry, B. and Alvi, (2011) 'We are all vulnerable': the in terrorem effects of hate crimes. International Review of Victimology, 18(1), pp. 57-71.

Perry, J. (2009) At the intersection: hate crime policy and practice in England and Wales. Safer Communities, 8(4), pp. 9-18.

Pezzella, F S. and Fetzer, M D. (2017) The likelihood of injury among bias crimes: an analysis of general and specific bias types. Journal of Interpersonal Violence, 32(5), pp. 703-729.

Phillips, N D. (2009) The prosecution of hate crimes: the limitations of the hate crime typology. Journal of Interpersonal Violence, 24(5), pp. 883-905.

Polisen (2015) Återredovisning av regeringsuppdraget beträffande hatbrott. Rapport A121.608/2014: 426.

Popper, K. (2002) Conjectures and refutations: the growth of scientific knowledge. London: Routledge.

Proposition 1993/94: 101 Åtgärder mot rasistisk brottslighet och etnisk diskriminering $\mathrm{i}$ arbetslivet

Proposition 2001/02: 59 Hets mot folkgrupp, m.m

Regeringskansliet (2016) Nationell plan mot rasism, liknande former av fientlighet och hatbrott. Kulturdepartementet.

Rikspolisstyrelsen (2013) Inspektion av polismyndigheternas förmåga att upptäcka och utreda hatbrott. Tillsynsrapport 2013:4.

Roulstone, A. and Mason-Bish, H. (2013) Disability, hate crime and violence. London: Routledge.

Sagan, C. (1996) The demon haunted world: science as a candle in the dark. New York: Ballantine Books. 
Sidanius, J. and Pratto, F. (1999) Social dominance. Cambridge: Cambridge University Press.

Smith, K. Lader, D. Hoare, J. and Lau, I. (2012). Hate crime, cyber security and the experience of crime among children: Findings from the 2010/11 British crime survey. London, UK: Home Office.

Soares, P. (2017) Varför ses inte brott mot kvinnor som hatbrott?. Östra Småland Nyheterna. Available at http://www.ostrasmaland.se/insandare/varfor-ses-intebrott-mot-kvinnor-som-hatbrott/. Accessed $16^{\text {th }}$ of April, 2018.

SOU 1991:75 Organiserad rasism, EDU:s delbetänkande om åtgärder mot rasistiska organisationer. Arbetsmarknadsdepartementet.

SOU 2000:88 Organiserad brottslighet, hets mot folkgrupp, hets mot homosexuella, m.m. - straffansvarets räckvidd. Justitiedepartementet.

SOU 2008:85 Straff i proportion till brottets allvar. Justitiedepartementet.

Tiby, E. (1999) Hatbrott? Kriminologiska Institutionen, Nr. 1, Stockholms Universitet.

Triffleman, E. and Pole, N. (2010) Future directions in studies of trauma among ethnoracial and sexual minority samples: commentary. Journal of Consulting and Clinical Psychology, 78(4), pp. 490-497.

Wallegren, S. and Mellgren, C. (2015) The role of visibility for a minority's exposure to (hate) crime and worry about crime: a study of the Traveller community. International Review of Victimology, 21(3), pp. 303-319.

Wallengren, S. and Mellgren, C. (2017) Gatans tysta offer: en studie av utsatta EUmedborgares utsatthet för brott, hatbrott och annan kränkande behandling i det offentliga rummet. Malmö högskola, FoU rapport 2017:4.

Walters, M A. (2010) A general theories of hate crime? Strain, doing difference and self control. Critical Criminology.

Weinstein, J. (1992) First amendment challenges to hate crime legislation: where's the speech? Criminal Justice Ethics, 11(2), pp. 6-15.

Wigerfelt, A. and Wigerfelt, B. (2016) Media images and experiences of being a Jew in the Swedish city of Malmö. Sage Open, pp. 1-14.

Wigerfelt, A. Wigerfelt, B. and Dahlstrand, K-J. (2015) Online hate crime: social norms and the legal system. Quaestio Iuris, 8(3): 1859-1878.

Wigerfelt, B. and Wigerfelt, A. (2015) Anti-gypsyism in Sweden: Roma's and Travelers' experiences of bias-motivated crime. Internet Journal of Criminology, pp. 1-28.

Wigerfelt, B. Wigerfelt, A. and Kiiskinen, J. (2014) When colour matters: policing hate crime. Social Inclusion, 2(1), pp. 1-11. 



\section{Malmö University Health and Society Doctoral Dissertations}

Ross, M. W. Typing, doing and being. A study of men who have sex with men and sexuality on the Internet. 2006:1

Stoltz, P. Searching for meaning of support in nursing. A study on support in family care of frail aged persons with examples from palliative care at home. 2006:2

Gudmundsson, P. Detection of myocardial ischemia using real-time myocardial contrasts echocardiograpy. 2006:3

Holmberg, L. Communication in palliative home care, grief and bereavement. A mother's experiences. 2007:1

Ny, P. Swedish maternal health care in a multiethnic society - including the fathers. 2007:2

Schölin, T. Etnisk mångfald som organisationsidé. Chefs- och personalpraktiker i äldreomsorgen. 2008:1

Svensson, O. Interactions of mucins with biopolymers and drug delivery particles. 2008:2

Holst, M. Self-care behaviour and daily life experiences in patients with chronic heart failure. 2008:3

Bahtsevani, C. In search of evidence-based practices. Exploring factors influencing evidence based practice and implementation of clinical practice guidelines. 2008:4

Andersson, L. Endocytosis by human dendritic cells. 2009:1.

Svendsen, I. E. In vitro and in vivo studies of salivary films at solid/liquid interfaces. 2009:2.

Persson, K. Oral health in an outpatient psychiatric population. Oral status, life satisfaction and support. 2009:3.

Hellman, P. Human dendritic cells. A study of early events during pathogen recognition and antigen endocytosis. 2009:4.

Baghir-Zada, R. Illegal aliens and health (care) wants. The cases of Sweden and the Netherlands. 2009:5.

Stjernswärd, S. Designing online support for families living with depression. 2009:6.

Carlsson, A. Child injuries at home - prevention, precautions and intervention with focus on scalds. 2010:1.

Carlson, E. Sjuksköterskan som handledare. Innehåll i och förutsättningar för sjuksköterskors handledande funktion i verksamhetsförlagd utbildning - en etnografisk studie. 2010:2.

Sinkiewicz, G. Lactobacillus reuteri in health and disease. 2010:3.

Tuvesson, H. Psychiatric nursing staff and the workplace. Perceptions of the ward atmosphere, psychosocial work environment, and stress. 2011:1.

Ingvarsdotter, K. Mental ill health and diversity. Researching human suffering and resilience in a multicultural context. 2011:2.

Hamit-Eminovski, J. Interactions of biopolymers and metal complexes at biological interfaces. 2011:3. 
Mellgren, C. What's neighbourhood got to do with it? The influence of neighbourhood context on crime and reactions to crime. 2011:4.

Annersten Gershater, M. Prevention of foot ulcers in patients with diabetes mellitus. Nursing in outpatient settings. 2011:5.

Pooremamali P. Culture, occupation and occupational therapy in a mental care context- the challenge of meeting the needs of Middle Eastern immigrants. 2012:1

Gustafsson A. Aspects on sepsis: treatment and markers. 2012:2

Lavant, E. Multiplex HLA-DR-DQ genotyping. For genetic epidemiology and clinical risk assessment. 2012:3

Wangel, A-M. Mental ill-health in childbearing women. Markers and risk factors. 2012:4

Scaramuzzino, R. Equal opportunities? - A cross-national comparison of immigrant organisations in Sweden and Italy. 2012:5

Ivert, A-K. Adolescent mental health and utilisation of psychiatric care - The role of parental country of birth and neighbourhood of residence 2013:1

Znamenskaya, Y. Effect of hydration on thermodynamic, rheological and structural properties of mucin. 2013:2

Andersson, F. The female offender. Patterning of antisocial and criminal activity over the life-course. 2013:3

Lindroth, M. Utsatthet och sexuell hälsa - en studie om unga på statliga ungdomshem. 2013:4

Hulusjö, A. The multiplicities of prostitution experience - narratives about power and resistance. 2013:5

Falk, M. Direct electron transfer based biofuel cells. Operation in vitro and in vivo. 2014:1

Finnbogadóttir, H. Exposure to domestic violence during pregnancy. Impact on outcome, midwives' awareness, women's experience and prevalence in the south of Sweden. $2014: 2$

Fagerström, A. Effects of surfactant adjuvants on barrier properties of plant leaf cuticle. 2014:3

Lamberg, P. Design and characterization of direct electron transfer based biofuel cells including tests in cell cultures. 2014:4

Richert, T. Överdoser, försörjningsstrategier och riskhantering - livsvillkor för personer som injicerar narkotika. 2014:5

Örmon, K. Experiences of abuse during the life course. - Disclosure and the care provided among women in a general psychiatric context. 2014:6

Sjöblom, I. Planerade hemförlossningar i Norden - kvinnors och barnmorskors perspektiv. 2014:7

Albèr, C. Humectants and Skin - Effects of hydration from molecule to man. 2015:1

Kisch M., A. Allogeneic stem cell transplantation. - Patients' and sibling donors' perspectives. 2015:2

Weiber, I. Children in families where the mother has an intellectual or developmental disability - incidence, support and first person perspectives. 2015:3 
Schlyter, M. Myocardial infarction, Personality factors, Coping strategies, Depression and Secondary prevention 2016:1

Carlström, C. BDSM - Paradoxernas praktiker. 2016:2

El-Schich, Z. Novel imaging technology and tools for biomarker detection in cancer. 2016:3

Boonsatean, W. Living with type 2 diabetes in Thai population: Experiences and socioeconomic characteristics. 2016:4

Vejzovic, V. Going through a colonoscopy and living with inflammatory bowel disease: Children's and parents' experiences and evaluation of the bowel cleansing quality prior to colonoscopy. 2016:5

Isma, G.E. Overweight and obesity in young children: Preventive work in child health care with focus on nurses' perceptions and parental risk factors. 2016:6

Brännvall, M. Frigörelse med förhinder - Om polisanmälan när kvinnor tar sig ur mäns våld i nära relationer. 2016:7

Pankratov, D. Self-charging biosupercapacitors. 2016:8

Guidi, P. Social work assessment of families with children at risk: Similarities and differences in Italian and Swedish public social services. 2016:9

Jakobsson, J. The process of recovery after colorectal cancer surgery: Patients' experiences and factors of influence. 2017:1

Gerell, M. Neighborhoods without community. Collective efficacy and crime in Malmö, Sweden. 2017:2

Wierzbicka, C. New fractionation tools targeting elusive post-translational modifications. 2017:3

Afzelius, M. Families with parental mental illness: Supporting children in psychiatric and social services. 2017:4

Nordgren, J. Making drugs ethnic - Khat and minority drug use in Sweden. 2017:5

Nilsson, E-L. Parental socialization and adolescent offending. 2017:6

Sixtensson, J. Härifrån till framtiden. Om gränslinjer, aktörskap och motstånd i tjejers vardagsliv. 2018:1

Vasiljevic, Z. Ambulatory risk assessment and intervention in the prison services. Using Interactive Voice Response to assess and intervene on acute dynamic risk among prisoners on parole. $2018: 2$

González Arribas, E. Flexible and transparent biological electric power sources based on nanostructured electrodes. 2018:3

Svalin, K. Risk assessment of intimate partner violence in a police setting. Reliability and predictive accuracy. 2018:4

Andersson, M. Hate crime victimization: consequences and interpretations. Consequences and interpretations. 2018:5

The publications are available online.

See www.mah.se/muep 


Hate crime studies is a young field in which in theoretical propositions or conclusions drawn in a single or a few studies have a large impact. Consequently, the present dissertation has two primary aims: I) to test field assumptions and 2) develop present theoretical frameworks on causes and consequences of hate crime.

In Articles I-4, me and my co-authors reject three of the four field

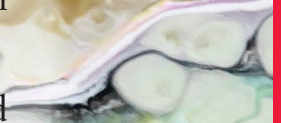
assumptions tested. The results call for a mere complex understanding of both causes and consequences of hate crime. To further the theoretical and empirical development of the field, I develop several falsifiable hypotheses that can be tested in future studies.

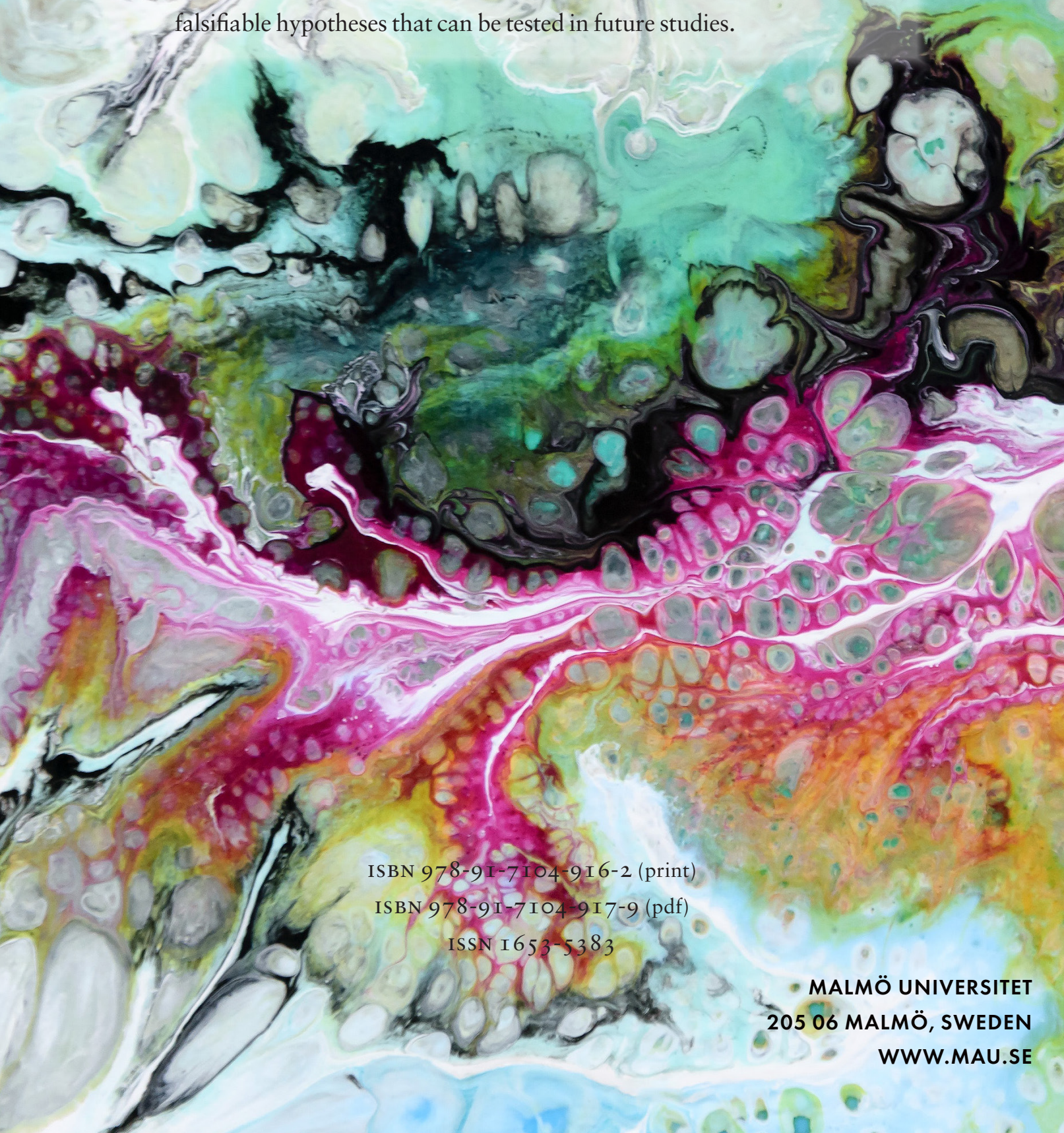

